\title{
Por uma carta dos bens fundamentais ${ }^{1}$
}

\author{
Luigi Ferrajoli ${ }^{2}$
}

Resumo: Este artigo questiona a possibilidade de a estipulação dos direitos fundamentais, e suas obrigações e proibições correspondentes, ser suficiente para garantir adequadamente as necessidades e os interesses vitais, em especial aqueles de interesse coletivo. São bens fundamentais aqueles cujo acesso é garantido a todos e a cada um, visto que são objetos dos direitos fundamentais subtraídos à lógica do mercado. A garantia de novos bens como bens fundamentais exige uma decisão política civilizatória de submeter ao direito as relações de mercado. Assim, às cartas e convenções internacionais e constitucionais de direitos fundamentais deveriam ser acrescentadas Cartas Constitucionais e Cartas Internacionais de bens fundamentais. Daí a necessidade de uma nova dimensão do constitucionalismo garantista: a longo prazo, além de global, para além da lógica individualista dos direitos e da miopia, e do estreito localismo da política das democracias nacionais.

Palavras-chave: Bens fundamentais. Direitos fundamentais. Garantismo.

\begin{abstract}
This article addresses the question of whether the stipulation of fundamental rights and obligations and prohibitions related to them is sufficient to properly ensure the needs and vital interests, especially those from collective interest. Fundamental goods are those whose access is guaranteed to each and every one since they are the object of fundamental rights, excluded from the logic of the market. The warranty for new goods and basic goods in the bottom of civilization requires a political decision to submit the right market relations. Thus, to the international charters and conventions and fundamental constitutional rights should be added Charters and international charter of basic goods. Hence the need for a new dimension of the constitutionally guaranteed: a constitutionally guaranteed in the long term, and global, apart from the individualistic logic of rights and shortsightedness and narrow localism policy of national democracies.
\end{abstract}

Keywords: Fundamental goods. Fundamental rights. Warrantism.

1 Tradução de Daniela Cademartori (UNIVALI/SC) (daniela_cademartori@yahoo.com. br) e Sergio Cademartori (UFSC) (scademartori@uol.com.br)

2 Professor de Filosofia do Direito e de Teoria Geral do Direito na Università degli Sudi Roma Tre. Dentre outras obras, escreveu Diritto e ragione. Teoria del garantismo penale; Principia iuris. Teoria del diritto e della democrazia; Teoria assiomatizzata del diritto; Democrazia autoritária e capitalismo maturo, em colaboração com Danilo Zolo, e La cultura giuridica nell'Italia del Novecento. 


\section{Introdução}

Na tradição do constitucionalismo democrático, as necessidades e os interesses vitais das pessoas estipuladas como merecedoras de tutela têm sido expressados quase sempre sob a forma de direitos fundamentais: da vida à integridade pessoal; da liberdade à sobrevivência; da instrução à saúde; todos os valores essenciais e vitais, desde sempre proclamados nas cartas constitucionais como fundamento e razão de ser do edifício jurídico, e que foram inicialmente reivindicados, e posteriormente reconhecidos e tutelados através da atribuição, aos indivíduos, de expectativas, ou de pretensões ou faculdades, concebidas sempre como direitos subjetivos. Paralelamente, foram, sobretudo, para não dizer somente, os direitos fundamentais os que delinearam aquele sistema de limites e vínculos substanciais aos poderes públicos que os quais denominei "esfera do indecidível”, formada por aquilo que a nenhum poder, nem mesmo à maioria, é consentido decidir ou não decidir.

A questão que tentarei abordar é: se a estipulação de tais direitos, e as obrigações e proibições correspondentes a eles, é suficiente para assegurar uma garantia adequada a todas as necessidades e a todos os interesses vitais, particularmente aqueles de tipo coletivo. É suficiente, por exemplo, o reconhecimento do direito de todos a viver num planeta habitável - ao não aquecimento global, a não poluição dos mares, a não depredação dos recursos naturais - para sugerir as formas de prevenção de catástrofes provocadas por esses eventos, cujas dimensões vão muito além das possibilidades de intervenção de qualquer jurisdição? A atribuição a todos do direito à vida e à saúde, embora estatuído em tantas cartas constitucionais e internacionais, é capaz de garantir a vida e a saúde aos milhões de pessoas que hoje vivem na indigência e que, na quase totalidade dos casos, não têm um juiz perante o qual demandar justiça, tanto pela inexistência de tal juiz, ou porque não possuem os meios para requerê-la? Naturalmente, a afirmação de tais direitos e das respectivas obrigações e proibições é essencial para a sua tutela. Mas é ela, também, nos casos exemplificados, suficiente? 
Aquilo que caracteriza todas essas catástrofes e essas emergências está no fato de que os correlativos direitos, consistentes ora em expectativas negativas de não lesão, ora em expectativas positivas de prestação, têm por objeto os bens - a atmosfera, o equilíbrio ecológico, a água, a alimentação básica, os medicamentos essenciais - em cuja proteção ou prestação consiste a sua garantia. Este ensaio pretende evidenciar como a garantia desses bens, os quais denominarei "fundamentais", e seus direitos correlativos requerem disciplinamento autônomo e específico, que vão muito além dos interesses e direitos dos indivíduos singulares e da sua capacidade e possibilidade de intervenção.

\section{Uma redefinição do conceito de bens}

O termo "bens fundamentais” é desconhecido na linguagem jurídica usual. Com ele, designei uma subclasse dos bens que por sua vez são uma subclasse das coisas. "Coisa” e "bem” são por sua vez termos do léxico jurídico tradicional. São “coisas” todos aqueles objetos observáveis e tangíveis que possuem um valor de uso e são por isso utilizáveis pelos seres humanos. ${ }^{4}$ Não são “coisas”, por exemplo, todos os corpos físicos inacessíveis, dos quais é, portanto, impossível o uso, como um terreno situado na lua, ou as estrelas, ou os minerais localizados no centro da

3 Em Principia iuris. Teoria del diritto e della democrazia, Laterza, Roma-Bari 2007, I. Teoria del diritto, cap. XI, § 11.10, p. 776. Antecipei a noção de "bens fundamentais” e a classificação de tais bens em "personalíssimos", "comuns" e "sociais" em Diritto civile e principio di legalità, in Il diritto civile oggi. Compiti scientifici e didattici del civilista, Edizioni Scientifiche Italiane, Napoli 2006, p. 81-91 e in La crisis de la democracia en la era de la globalización, in M. Escamilla y M. Saavedra (Ed.), Derecho y justicia en una sociedad global - Law and justice in a global society, in "Anales de la Cátedra Francisco Suárez", n. 39, 2005, p. 37-66.

4 Lembro de algumas das definições escolásticas mais difundidas: “coisa é uma qualquer porção do mundo externo que seja suscetível de ser utilizada” (G. MESSINEO, 1957, I, $\S$ 25.2, p. 380); “coisa” é qualquer "entidade material impessoal” (BARBERO, 1965, $\S \S 138$ e 141, p.219 e 221); "coisa” é uma parte \da matéria...que possa ser fonte de utilidade e objeto de apropriação” (TORRENTE; SCHLESINGER, 1994, § 58, p. 108); "são 'coisas' aquelas entidades (ou porções) da realidade natural que são suscetíveis de gozo de forma exclusiva” (MESSINETTI, 1979). 
Terra. Mas o são, por sua vez, os objetos úteis porque utilizáveis pelo homem. Além dos bens materiais, também as coisas acessíveis e disponíveis a todos, como o ar, a energia solar, os animais, os peixes do mar, e, em geral, a res nullius.

Quanto aos bens, a sua definição corrente na doutrina jurídica é aquela oferecida pelo art. 810 do código civil italiano: "São bens as coisas que podem ser objeto dos direitos”. Neste sentido, prossegue o código, os bens se distinguem em bens imóveis e bens móveis. "São bens imóveis”, diz o art. 812, “o solo, as nascentes, os cursos d’água, as árvores, os edifícios e outras construções, mesmo se unidas ao solo de forma transitória, e em geral tudo aquilo que naturalmente ou artificialmente é incorporado ao solo. São móveis, todos os outros bens". Em outras palavras, são “imóveis” todos aqueles bens que não podem ser transferidos materialmente, pelo que a sua venda, como diz o art. 1350 n. 1 do código, deve fazer-se através de ato escrito. São “móveis” todos os bens que podem mover-se e são por isso, transferíveis materialmente, mediante entrega, juntamente com a sua posse. Há ainda outras divisões dos bens, até de tipo naturalista, operados pela doutrina: entre bens divisíveis e indivisíveis, fungíveis e infungíveis; entre bens consumíveis e não consumíveis e ainda deterioráveis.

Em todas estas acepções a noção de bem designa, evidentemente, apenas os "bens patrimoniais", enquanto tais virtualmente disponíveis e alienáveis, já que configuram "objetos de direito” patrimoniais. Não por acaso a definição de bens oferecida pelo citado art. 810 abre o Livro III do código civil sobre a propriedade privada, isto é, sobre o mais clássico e importante dos direitos patrimoniais, e sobre os outros direitos reais. Uma coisa torna-se um bem patrimonial quando, por sua escassez e por seu valor de troca, faz-se objeto de um direito patrimonial específico. ${ }^{5}$

\footnotetext{
5 Sob este aspecto, a distinção entre "bens patrimoniais" e outras "coisas" (inclusive os bens fundamentais) exige a distinção marxiana entre "valor de uso" e "valor de troca”. De fato, pode-se dizer, sobre a base desta distinção, que as coisas são todas e tão somente as entidades que possuem um valor de uso, no sentido de que podem ser utilizadas; enquanto os bens patrimoniais são somente as coisas que têm, além de um valor de uso, um valor de troca, no sentido de que é possível dispor e trocar no mercado.
} 
No entanto, existem bens que não são coisas, como todos aqueles que a doutrina, acolhendo a noção civilista dos "bens" como coisas, isto é, como entidades materiais, chama contraditoriamente de "bens imateriais", isto é, não corpóreos nem concretamente tangíveis: as obras do talento ou as invenções industriais objetos de patente, as criações intelectuais objetos de direitos de autor, as marcas e os produtos financeiros. ${ }^{6}$ E existem bens que não são objeto de direitos patrimoniais, como o ar, as áreas e fundos marinhos e os órgãos do corpo humano, cujo traço distintivo, contrariamente àquele dos bens patrimoniais, é a sua indisponibilidade, isto é, a sua subtração ao mercado enquanto bens, como chamados pelos romanos, extra commercium e extra patrimonium.

A definição legislativa fornecida pelo art. 810 do código civil, embora tenha o mérito da simplicidade, é, no plano da teoria do direito, duplamente restrita e, portanto carente de uma adequada capacidade explicativa: porque limita os bens apenas às coisas, e, mais do que isso, apenas às coisas que são objetos de direitos patrimoniais. Para dar conta de todos os bens que não são nem coisas nem bens patrimoniais, e que, no entanto, são relevantes como objeto de tutela e de todas formas de disciplina jurídica, é útil assumir uma definição teórica mais ampla:

6 Assim, por exemplo, Are (1959, p. 244-270), quem, depois de sustentar que os bens são coisas no sentido material de "porções da realidade objetiva” (p. 247), define os "bens imateriais” ou "intelectuais” como "entidades do pensamento” e "construções do pensamento individual” (p. 250). Analogamente, Comporti (BESSONE, 2003, p. 347), que igualmente acolhe a noção de bem como coisa tal como a adotada pelo art. 810 do código civil, entendida a "coisa” no sentido de "porção do mundo externo perceptível com os sentidos"; mas distingue após entre bens materiais e bens imateriais definindo estes últimos como entidades dotadas de "uma existência puramente ideal". Mas, anteriormente, a contradição já havia sido expressa por Bernard Windscheid: "Por coisa se entende todo objeto singular pertencente à natureza irracional. Com isto se diz que, do conceito de coisa faz parte o momento da existência real, da corporeidade. Mas não é, no entanto, subtraído ao direito positivo tratar como corporais, absolutamente ou em relações singulares, coisas meramente fictícias enquanto objetos de relações jurídicas. Nessa medida, tranquilamente se poderá falar em coisas incorpóreas”, para designar assim também “obras científicas e artísticas, invenções etc.” (Lehrbuch des Pandektenrechts, [1862-1870], trad. It. De C. Fadda e P.E. Bensa, Diritto delle Pandette, Utet, Torino 1902, I, parte II, § 137, p. 1 e 4). 
“'bem’ é aquilo que pode ser objeto de uma situação jurídica”. ${ }^{7}$ Neste sentido, a noção de bem resulta mais extensa do que aquela usual sob dois aspectos. São "bens” com base naquela, não somente as coisas que são o objeto de direitos patrimoniais, mas ainda: a) os bens imateriais, que não são coisas, pelo menos se se acolhe a noção corrente de coisa como "porção do mundo externo perceptível pelos sentidos"; ${ }^{8}$ b) todos os bens que não são o objeto de direitos patrimoniais, dos assim chamados 'bens comuns', correspondentes aos romanísticos res communes omnium, como o ar, o solo oceânico e a biodiversidade, aos bens como os órgãos do corpo humano, dos quais, como diz o art. 5 do código civil italiano, são proibidos aos atos de disposição "quando ocasionam uma diminuição permanente da integridade física, ou são outrossim contrários à lei, à ordem pública ou aos bons costumes”; c) todos os bens, afinal, que são o objeto não já de direitos, mas de proibições, e que por isso podemos chamar de bens ilícitos porque é proibida a sua produção e/ou seu comércio e/ou sua utilização e/ou sua detenção. ${ }^{9}$

\section{Bens fundamentais e bens patrimoniais}

Sobre esta base, podemos formular duas grandes distinções. A primeira, ressaltada pela doutrina, embora operada contraditoriamente sobre a base da conotação de "bem” como “coisa” fornecida pelo art. 810

\footnotetext{
7 É a definição estipulada em Principia iuris cit. I, § 7.11, p. 392, D7.19.

8 M. Comporti, Le cose, i beni ed i diritti reali, loc. Ult. Cit. Confira-se também todas as definições de "coisa” referidas na nota 3.

9 Defini os bens ilícitos como aqueles bens cuja utilização ou negociação são proibidas como atos ilícitos, in Principia iuris, cit., I, § 11.11, D11.33, p. 784. Confira, ainda, Principia iuris, cit. II, § 16.9, p. 523-524 e §16.21, p. 584. Neste sentido, são bens ilícitos, por exemplo, as substâncias psicotrópicas. Mas também o são, ou deveriam sêlo, as armas, das quais em muitos ordenamentos são proibidos o porte ou a detenção sem licença e das quais seria a meu ver justificado um radical banimento, através da proibição, seja da sua produção, seja do seu comércio e de sua detenção: trata-se com efeito de bens destinados a matar e por isso de alimentar os dois fenômenos - a criminalidade e a guerra - em cuja prevenção, através do monopólio jurídico da força, reside a função primária do direito, que é a garantia do direito à vida e à paz.
} 
do código civil, é aquela feita entre bens materiais e imateriais: são bens materiais todos os bens consistentes em coisas; são bens imateriais todos os bens não consistentes em coisas, como as marcas, as obras do engenho humano e as criações artísticas ou intelectuais. ${ }^{10}$

A segunda distinção, bem mais importante, embora ignorada pela doutrina corrente, é aquela, à qual dediquei este ensaio, entre bens patrimoniais e bens fundamentais. Podemos chamar de bens patrimoniais os bens disponíveis no mercado através de atos de disposição ou de troca, a par dos direitos patrimoniais dos quais são o objeto, a cujos titulares é, portanto reservado o seu uso e gozo. Chamarei por outro lado de bens fundamentais os bens cuja acessibilidade é garantida a todos e a cada um porque objeto de outros tantos direitos fundamentais e que por isso, da mesma forma que estes, são subtraídos à lógica do mercado: o ar, a água e outros bens do patrimônio ecológico da humanidade e, ainda, os órgãos do corpo humano, os fármacos considerados "essenciais” ou "salvavidas” e similares. Temos assim uma distinção na qual é fácil reconhecer a analogia com a respectiva distinção dos direitos subjetivos em direitos patrimoniais e direitos fundamentais. ${ }^{11}$ As duas distinções residem na correlação sintática expressa pelas definições das duas classes de bens: aquela de bens patrimoniais como qualquer bem que seja objeto de um direito patrimonial, e aquela de bens fundamentais como qualquer bem que seja objeto de um direito fundamental primário. ${ }^{12}$ Naturalmente, enquanto todos os bens fundamentais são, por definição, objeto de direitos fundamentais, não é verdade a tese contrária: somente alguns direitos

10 Vejam-se as definições em Principia iuris cit., I, § 7.11, D7.20 e 7.21, I, p. 393-394: a distinção remonta ao direito romano: "Corporales hae quae tangi possunt, velut fundus homo vestis aurum argentum et denique aliae res innumerabiles. Incorporales sunt quase tangi non possunt, qualia sunt ea quae in iure consistunt, sicut hereditas usufructus obligationes quoquo modo contractae” (D 1, 8, 1, 1). É, pois, evidente que a distinção entre bens móveis e imóveis abrange somente os bens materiais.

11 Veja-se, sobre a distinção entre direitos fundamentais e patrimoniais e sobre os tratamentos que diferenciam as duas classes de direitos, Principia iuris cit., I $\S \S 11.1$ e 11.7, p. 724-731 e 759-766, D.11.1 e D11,9. Remeto ainda a Diritti fondamentali. Un dibattito teórico, (2001), III ed., Laterza, Roma-Bari 2008, I, p. 5-18 e II, p. 134-145.

12 Principia iuris cit, I, § 11.10, D11.27 e D11.28, p. 776-782. Veja-se ainda, id. II, § 14.21, p. 263-266; §16.21, p. 585 e §16.24, p. 596-603. 
fundamentais - tais como o direito à imunidade, o direito à integridade pessoal, e alguns direitos sociais, como o direito à saúde e à alimentação básica - têm como objeto bens fundamentais.

As duas distinções - entre os bens, e esta e a dos direitos - refletem, portanto, diferenças estruturais análogas. Os direitos fundamentais, segundo a definição por mim proposta, são todos aqueles direitos que dizem respeito universalmente a todos enquanto pessoas e/ou cidadãos e/ou pessoas com capacidade de fato, que, enquanto tais, são prescritos imediatamente por normas, as quais designei, por isso mesmo, "téticas" e precisamente "tético-deônticas”, sendo consequentemente indisponíveis e inalienáveis. ${ }^{13}$ Analogamente, também os direitos fundamentais são universais, no sentido de que seu desfrute é acessível a todos pro indiviso ou igualmente reservado a todos e a cada um de maneira exclusiva; são além disso, também qualificados como tais imediatamente por normas “téticas”, e precisamente "tético-constitutivas"; 14 são também, finalmente, subtraídos à disposição e à apropriação privada. Pelo contrário, os direitos

13 Id.,I,§11.1, pp.t24-731, D11.1. Denominei “normas téticas”, distinguindo-as em "deônticas” e “constitutivas”, as normas que dispõem imediatamente situações ou status jurídicos: por exemplo, as normas constitucionais que atribuem direitos fundamentais, ou as normas penais que proíbem determinados comportamentos como delitos, ou as normas do código civil que conferem a capacidade jurídica no momento do nascimento e a capacidade de fato ao completar 18 anos de idade. Designei como "normas hipotéticas”, igualmente divididas em “deônticas” e “constitutivas”, as normas que não dispõem imediatamente nada, mas predispõem situações ou status como efeitos dos atos por elas hipoteticamente previstos: por exemplo, as normas do código civil que predispõem a constituição de direitos patrimoniais e das obrigações correspondentes como efeito dos atos negociais por eles previstos, ou as normas penais que predispõem as penas pelos delitos nelas previstos, ou as normas do código civil que predispõem status, por exemplo de cônjuge, como efeito dos atos constitutivos; o matrimônio, por elas hipoteticamente previstos (id., I, §§ 8.2 e 8.3, p. 419-428 4.5-4.6, p. 233-239).

14 Idem, I, § 11.11, p. 783-784. São, por exemplo, normas tético-constitutivas os artigos do "Tratado sobre o espaço estratosférico” de 1967 e aqueles da "Convenção das Nações Unidas sobre o direito do mar” de 1982 que, como se verá na nota 27, qualificam como "patrimônio comum” da humanidade, isto é como "bens comuns", o espaço estratosférico, a área de alto mar e os seus recursos e o solo marinho. O são igualmente as normas do código civil que identificam os bens públicos, dos quais falarei no $\S 6$ e nas notas 38 e 39. 
patrimoniais são todos aqueles direitos que dizem respeito singularmente aos seus titulares com exclusão dos outros; que, enquanto tais, não são já diretamente dispostos, mas predispostos por normas ditas "hipotéticodeônticas” como efeito dos atos por elas hipoteticamente previstos, que são por isso disponíveis e alienáveis. ${ }^{15} \mathrm{E}$, analogamente, também os bens patrimoniais são bens singulares, no sentido de que seu desfrute é garantido exclusivamente aos titulares dos direitos patrimoniais dos quais são objeto; são predispostos por normas hipotético-deônticas juntamente com os respectivos direitos, dispostos como efeitos dos atos por elas hipoteticamente previstos; e são, por isso, a par dos direitos dos quais são objeto, disponíveis e alienáveis. ${ }^{16}$

No entanto, há uma diferença entre a indisponibilidade dos direitos fundamentais e a dos bens fundamentais. Enquanto a primeira é uma indisponibilidade conceitual lógica, e portanto, inviolável, ligada à natureza de generalidade, abstração e heteronomia das normas que estabelecem direitos fundamentais, a segunda é uma indisponibilidade somente jurídica, e portanto passível de violação, dado que os bens fundamentais, de fato, são sempre materialmente disponíveis. Por isso, a garantia da indisponibilidade de tais bens possui a forma de proibição, de fato violável, de disposição. Em suma, enquanto a indisponibilidade dos direitos fundamentais é do tipo alético, de tal modo que uma eventual disposição deles é sabidamente inexistente, aquela dos bens fundamentais é de tipo deôntico, pelo que uma sua eventual disposição seria apenas um ato ilícito. Um ato de venda da liberdade de consciência ou de manifestação do pensamento, por exemplo, seria irrealizável e sem sentido, dado que as normas que estabelecem tais liberdades são normas heterônomas cuja existência é independente de qualquer coisa que possamos pensar ou fazer. Pelo contrário, a venda ou a destruição de um bem fundamental são fatos, talvez irreversíveis, dos quais o direito não pode impedir a sua concreta comissão, mas somente proibi-la e puni-la como ilícita.

\footnotetext{
${ }^{15}$ Idem, § 11.7, p. 759-767, D11.18 e D11.19.

${ }^{16}$ Idem, § 10.11, PP. 776-782, D11.27
} 
Não é supérfluo acrescentar que para a ciência jurídica a natureza patrimonial ou fundamental de um bem depende do direito positivo: um bem fundamental, como, por exemplo, um órgão vital do corpo humano, tornar-se-á patrimonial se os direitos sobre ele se tornarem disponíveis; inversamente, bens patrimoniais, como, por exemplo, água ou os medicamentos essenciais, tornar-se-iam fundamentais se não fosse proibido o desperdício e fosse obrigatória a sua distribuição a todos. Pelo contrário, para uma teoria da justiça, são fundamentais todos e somente aqueles bens por ela assumidos como vitais e por isso merecedores de tutela, independentemente daquilo que estabelece o direito positivo. Finalmente, é diferente o ponto de vista aqui adotado de teoria do direito. ${ }^{17}$ Neste plano, a distinção não possui nada de ontológico. Não se diz quais bens são ou é justo que sejam fundamentais ou patrimoniais. Pode-se somente dar conta, em sede de teoria do direito, dos nexos entre bens e direitos patrimoniais e entre bens e direitos fundamentais. Os bens patrimoniais são objeto de direitos patrimoniais enquanto e somente enquanto - podem ser não somente utilizados, mas também desperdiçados segundo o clássico paradigma proprietário do ius utendi et abutendi. Pelo contrário, os bens fundamentais são objeto de direitos fundamentais enquanto - e somente enquanto - são objetos de limites ou vínculos, ou seja, das proibições de disposição ou de obrigações de prestação correspondentes a eles, como a proibição do comércio de órgãos ou a proibição da exploração da prostituição, as proibições das atividades poluidoras, aquelas que limitam ou impedem a apropriação de recursos não renováveis e por isso reconhecidos como comuns, ou as obrigações de distribuição de bens vitais, como a água, os alimentos básicos e os medicamentos essenciais.

17 Sobre a diversidade do estatuto epistemológico e do ponto de vista da teoria do direito com respeito ao estatuto e ao ponto de vista das disciplinas jurídicas positivas, tenho insistido outras vezes: remeto a Diritti fondamentali cit., cap.II, §§ 1 e 2, pp. 121-134 e cap. III, § 1, p. 279-282 e a Principia iuris cit., Introdução, em particular §§ 1.2-1.4 e 1.8 p. 8-20 e 39-43. 


\section{Uma tipologia dos bens fundamentais: bens personalíssimos, bens comuns e bens sociais. Por uma carta constitucional dos bens fundamentais}

Podemos distinguir, sobre a base da sua diversa estrutura, três grandes classes de bens fundamentais: a) os bens personalíssimos, que são objeto de direitos passivos consistentes unicamente em rígida imunidade ou "liberdade da" sua violação, sua apropriação ou utilização por parte de outros: como os órgãos do corpo humano cuja integridade perfaz um todo com a salvaguarda da pessoa e da sua dignidade; b) os bens comuns, que são objeto de direitos ativos de liberdade consistentes, além de imunidade de devastação e saque, também em faculdade ou “liberdade de” isto é, no direito de todos de aceder ao seu uso e gozo: o ar, o clima e os outros bens ecológicos do planeta, de cuja tutela depende o futuro da humanidade; ${ }^{18}$ c) finalmente, os bens sociais, que são objeto de direitos sociais à subsistência e à saúde garantidos pela obrigação da sua prestação: a água, os alimentos básicos e os assim chamados “medicamentos essenciais”. ${ }^{19}$

A necessidade de recorrer a estas categorias - os bens fundamentais e as três classes ora especificadas - com finalidade explicativa e, sobretudo, reivindicadora do papel garantista do direito, baseia-se nas mudanças provocadas na relação entre homem e natureza pelo desenvolvimento da indústria e tecnologia. Toda a história das coisas e dos bens é uma grande história social, no curso da qual, graças à sua crescente valorização e ao desenvolvimento tecnológico, muitos objetos, como, por exemplo, as matérias-primas, tornaram-se coisas à medida que foi descoberta a sua utilidade; muitas coisas, como, por exemplo, as terras incultas e seus frutos tornaram-se bens patrimoniais na medida do crescimento da escassez e esgotamento da sua ilimitada disponibilidade; muitas coisas e

\footnotetext{
18 A noção de bens comuns remonta ao direito romano: "Quaedam enim naturali iure communia sunt omnium, quaedam publica, quaedam universitatis, quaedam nullius pleraque singulorum, quae variis ex causis cuique adquiruntur. Et quidem naturali iure omnium communia sunt illa: aer, aqua profluens, et mare, et per hoc litora maris" (Inst., 2, 1 pr.; D 1,8,2,1).

19 São substancialmente essas as definições das três classes de bens fundamentais (D11.29, D11.30 e D11.31) estipulados em Principia iuris cit., cap. XI, § 11.10, p. 777-778.
} 
muitos bens patrimoniais, finalmente, como o ar e outros bens ecológicos, a água, os medicamentos essenciais e a alimentação básica tornaram-se ou seria justo que se tornassem - bens fundamentais quando se manifestou a sua vulnerabilidade e a sua não renovabilidade, ou, pelo contrário, a sua aptidão para serem produzidos e portanto a possibilidade de garanti-los a todos como fatores de sobrevivência.

Hoje é, sobretudo, esta última transformação, a de transformar em bens fundamentais muitas coisas e muitos bens patrimoniais, a que é exigida pelas mudanças tecnológicas e pelo desenvolvimento da cultura jurídica; em primeiro lugar, por causa do desenvolvimento das técnicas cirúrgicas de transplantes, a necessidade do reforço das garantias dos bens personalíssimos contra as muitas possibilidades, no passado nem sequer imagináveis, de atos de disposição e de alienação. Em segundo lugar, verifica-se a a transformação em bens comuns de muitos bens ecológicos que, até poucos anos atrás, não eram nem mesmo considerados bens, mas simplesmente coisas, como a água e a atmosfera, e que, a causa da superveniente escassez e vulnerabilidade devidas às crescentes agressões e devastações, têm-se revelado fundamentais para a sobrevivência do gênero humano. Requer-se, afinal, em razão do desenvolvimento tecnológico das indústrias farmacêutica e alimentícia - o qual tornou possível a produção artificial e a distribuição a todos dos múltiplos bens vitais, como os medicamentos essenciais e muitos bens alimentícios -, a qualificação de tais bens como bens sociais, acessíveis a todos, como garantia dos direitos de todos à sobrevivência e à saúde.

Estas mudanças de status, das coisas e dos bens, requerem, todas elas, a intervenção do direito. Diversamente das transformações dos objetos em coisas e de coisas em bens patrimoniais, determinadas ambas pela sua crescente escassez e valorização, a garantia de novas coisas e novos bens como bens fundamentais requer de fato uma escolha política civilizatória: a decisão de submeter ao direito as relações de mercado. A simples valorização econômica, com efeito, na ausência de uma intervenção pública, pode muito bem determinar - e de fato tem frequentemente determinado -, em contraste com interesses públicos vitais, o processo exatamente oposto: a privatização desses mesmos bens, transformados de 
bens comuns e, portanto, fundamentais, em bens patrimoniais. Em suma, a apropriabilidade originária e disponibilidade natural de muitas coisas como tem sido tipicamente a água potável - é destinada a tornar-se, pela crescente escassez, uma apropriação e uma disponibilidade jurídica, que somente se verificará sob a forma de bens fundamentais comuns, mais do que naquela de bens patrimoniais, podendo assim ser garantida a todos e preservada da dissipação, destruição e especulação privada. Inversamente, a originária inapropriabilidade e indisponibilidade natural de muitos objetos, como, por exemplo, os órgãos do corpo humano, tornouse, em consequência da adquirida e experimentada apropriabilidade tecnológica, uma respectiva apropriabilidade e disponibilidade jurídicas que, novamente, somente se verificará sob a forma de bens fundamentais personalíssimos, mais do que sob a forma de bens patrimoniais, podendo assim ser impedida e penalizada como tutela dos sujeitos mais fracos. Afinal, a destruição dos bens ecológicos poderá ser proibida somente se tais bens forem garantidos a todos como bens fundamentais comuns, e a distribuição dos medicamentos essenciais poderá se tornar obrigatória somente se tais bens forem garantidos a todos como bens fundamentais sociais, em vez de serem aqueles tratados simplesmente como coisas e esses como bens patrimoniais.

Entende-se, dadas as dimensões e a dramática gravidade dessas mudanças, a necessidade de acrescentar à categoria dos direitos fundamentais aquela não menos essencial dos bens fundamentais, distinguidos nas três classes de bens personalíssimos, bens comuns e bens sociais. A linguagem dos direitos, mesmo que fundamentais, resulta totalmente inadequada para formular as técnicas de tutela exigidas por cada um desses bens. Precisamente, isso é suficiente para tematizar as formas de tutela somente dos bens personalíssimos, consistentes, ao lado dos direitos dos quais são objeto, em imunidades individuais garantidas por outras tantas proibições fundamentais. Mas ela é totalmente inadequada para os bens sociais, e não o é de todo para os bens comuns, seja assumindo, em contraste com a gramática do direito, como titulares, além das pessoas singulares, a própria natureza, ${ }^{20}$ seja identificando esses

${ }^{20}$ Aos "direitos da natureza” é dedicado o capítulo VII do Título II da Constituição do Equador de 2008: "a natureza”, diz o art. 71, "tem o direito de que se respeite integralmente 
titulares com sujeitos coletivos, como os povos, a comunidade ou talvez a humanidade inteira. ${ }^{21}$

Ao contrário, são os bens, enquanto vitais e por isso fundamentais, que são assumidos como objeto de garantia, em acréscimo aos respectivos direitos fundamentais, através da introdução de proibições de sua lesão ou de obrigações de sua prestação, mais do que as funções e instituições de garantia voltadas à sua tutela ou à sua distribuição. Nessa perspectiva, às muitas cartas e convenções internacionais e constitucionais dos direitos fundamentais, deveriam ser acrescentadas Cartas constitucionais e Cartas internacionais dos bens fundamentais, idôneas, por um lado, como garantia dos bens personalíssimos e dos bens comuns para impor limites rigorosos ao mercado e ao desenvolvimento industrial; por outro lado, como garantia dos bens sociais, para vincular a política para tornálos acessíveis a todos. ${ }^{22}$ Tratar-se-ia de normas téticas no sentido acima

a sua existência e a manutenção e regeneração de seus ciclos vitais, estruturas, funções e processos evolutivos. Toda pessoa, comunidade, povo ou nacionalidade poderá pretender da autoridade pública a observação dos direitos da natureza”; e o art. 72: “a natureza tem direito a intervenções de restauração”. De "direitos da natureza”, isto é, atribuídos à natureza, tem falado, com variedade de acentos, T. C. Stone, Should Trees Have Standing? Toward Legal Rights for Natural Objects, Tioga Publishing Co., Palo Alto 1988; R. F. Nash, The Rights of Nature, The University of Wisconsin Press, Madison 1989; M. Tallacchini, Diritto per la natura. Ecologia e filosofia del diritto, Giappichelli, Torino 1996, cap.V, § 5.2.1.2, p.238-241. De um "vero e proprio diritto della natura" falou ainda F. Viola, Dalla natura ai diritti. I luoghi dell'etica contemporanea, Laterza, Roma-Bari 1997, cap.I, § 4, p. 57.

21 Aos “direitos das comunidades, dos povos e da nacionalidade” é dedicado o capítulo IV do Título II da já mencionada Constituição do Equador, que arrola tais direitos sobretudo no art. 57 (cujos ns. 4-8, 11 e 13 referem-se a bens comuns). Vejam-se também os arts. 339, 343, 349 da Constituição da Bolívia de 2008. Da humanidade como sujeito jurídico imputável, junto aos seres humanos singulares, de direitos fundamentais para salvaguarda das condições de vida de nosso planeta tem falado Senese (BALDUCCI, 2000) e Viola (2000, p. 186-188).

22 Uma Carta mundial da natureza (World Charter for Nature) foi aprovada em 28/10/1982 pela Assembleia Geral da ONU. Recorde-se também, entre as principais Declarações e convenções internacionais para a tutela do ambiente, a Declaração de 16 de junho de 1982, aprovada como conclusão da Conferência de Estocolmo sobre o ambiente; a "Declaração sobre o ambiente e o desenvolvimento" ou "Carta da Terra" (Earth Charter) aprovada pela Conferência da ONU realizada no Rio de Janeiro em junho 
ilustrado: isto é, de normas que, diferentemente das normas hipotéticas que disciplinam a troca de bens patrimoniais, constituiriam elas mesmas tais bens como fundamentais, não diversamente de como fazem as atuais normas do código civil, que constituem tais bens como "bens públicos", como se verá mais adiante; somente que deveria tratar-se de normas de nível constitucional e, se necessário, de nível internacional, donde os limites e vínculos impostos ao mercado e à política para a tutela de tais bens são resguardados das violações do legislador ordinário e por isso das maiorias contingentes.

A natureza desses limites e vínculos e seu grau de rigidez dependem naturalmente do caráter mais ou menos vital dos bens fundamentais que se tenta proteger e das formas de sua possível utilização: do caráter regenerável ou não regenerável tanto das partes do corpo humano como dos bens ecológicos, do caráter gratuito da sua cessão e dos usos aos quais são destinados. Proteger um bem como fundamental quer dizer em todo caso torná-lo indisponível, isto é, inalienável e inviolável e, portanto, subtraí-lo ao mercado e ao arbítrio das decisões políticas, portanto de maioria. Também sob este aspecto, os bens fundamentais reafirmam

de 1992, junto a duas convenções-quadro vinculantes: a Convenção sobre a mudança climática (Framework Convention on Climate Change) e aquela sobre a diversidade biológica (Convention on Biological Diversity); o protocolo de Kyoto de dezembro de 1997 que começou a vigorar em 15 de fevereiro de 2005, que impõe, contra a poluição atmosférica e a destruição do ozônio, reduções apenas de 5,2\% das emissões poluentes em 2008, a cuja ratificação no entanto negaram-se muitos países poluentes entre eles dos Estados Unidos. Recorde-se, ainda, os artigos 2 e 174-176 do Tratado de Amsterdam, que atribuem à Comunidade Europeia "a tarefa de promover... um elevado nível de proteção e a melhoria da qualidade deste último" e preveem para tal finalidade medidas adotadas mediante procedimentos de codecisão. Todas estas normas são claramente inadequadas perante a gravidade do desafio do atual desenvolvimento insustentável. Faltam, de fato, instituições de garantia primárias e secundárias dos bens comuns, em grau de impor limites rigorosos às atividades industriais nocivas à saúde e ao ambiente e para assegurarlhes efetividade com formas adequadas de responsabilidade penal, civil e administrativa. Remeto, sobre estes problemas, além de Principia iuris cit., II, § 16.21, p. 582-587, a M. Tallacchini, op. cit., cap. V, p. 202. Mas faltam também adequadas garantias dos bens sociais - da água à alimentação básica e aos medicamentos essenciais - as quais requereriam, sobretudo, a introdução de instituições de garantia primária, para efeitos de distribuir a todos tais bens. 
o paradigma dos direitos fundamentais - dado que as suas garantias também equivalem a limites e a vínculos impostos para a tutela de todos e de cada um, seja aos poderes privados, através da estipulação da sua indisponibilidade, seja aos poderes públicos, através da estipulação da sua inviolabilidade, - e ao mesmo tempo, a obrigação de garantir a todos a sua fruição. Podemos acrescentar que, se as cartas de direitos fundamentais evocam a ideia do "contrato social” de convivência pacífica entre os homens, uma carta internacional dos bens fundamentais configurar-seia numa espécie de "contrato natural" de convivência com a natureza ${ }^{23}$ e poderia abrir-se, parafraseando o preâmbulo da Carta da ONU, com as palavras: "Nós, povos das Nações Unidas, decididos a salvar as futuras gerações do flagelo do desenvolvimento insustentável, que, no curso desta geração, tem provocado indizíveis devastações ao nosso ambiente natural; decididos ademais para assegurar a todos a garantia dos mínimos vitais e para impedir violações dos corpos das pessoas, possibilitados ambos pelo progresso tecnológico, acordamos [...]” as seguintes medidas urgentes para garantir os seguintes bens fundamentais da humanidade.

Para identificar essas medidas e essas garantias em relação aos diversos tipos de bens protegidos, distinguirei duas ordens de diferenças estruturais entre as classes de bens nas quais diferenciei todos os bens fundamentais. A primeira é aquela, que já apontei, referente à sua diferente relação com os direitos fundamentais dos quais são objeto: enquanto os bens personalíssimos são tutelados pelas garantias dos respectivos direitos de imunidade dos quais são indissociáveis, as garantias dos bens comuns e dos bens sociais requerem instituições públicas voltadas de modo geral à sua proteção ou à sua prestação. É claro que essas garantias não podem limitar-se apenas às garantias dos direitos respectivos, exigindose também o desenvolvimento de complexos aparatos administrativos, voltados, como se verá nos $\S \S 6$ e 7, a funções específicas de tutela dos bens comuns e de distribuição ope leges dos bens sociais.

Além disso, há também uma segunda diferença: os bens personalíssimos e os comuns são bens naturais, objeto de direitos negativos de imunidade - os primeiros dos quais bem podem ser chamados de direitos

${ }^{23}$ É o título do ensaio de Serres (1991). 
biológicos à integridade pessoal; os segundos podemos chamá-los de direitos ecológicos à integridade do ambiente - consistentes todos em expectativas negativas às quais correspondem, como garantias, proibições de lesão. Os bens sociais, ao invés, são bens prevalentemente artificiais, objeto de direitos sociais positivos, consistentes todos em expectativas positivas às quais correspondem, como garantia, obrigações de prestação. São consequentemente diferentes as garantias exigidas pelas duas classes de bens. As garantias dos bens fundamentais naturais, sejam eles personalíssimos ou comuns, residem na sua indisponibilidade, conexa ao fato de que os bens personalíssimos constituem-se como um todo indissociável da integridade da pessoa, pertencendo aos seus titulares e a nenhum outro; e os bens comuns são patrimônio comum da humanidade, pertencendo a todos sem exclusão. Ao contrário, as garantias dos bens fundamentais sociais, como a água, a alimentação e os medicamentos essenciais, residem na obrigação pública da sua prestação, consequência do fato de que, sendo eles produzidos ou distribuídos pelo homem, não pertencem por si mesmos a todos, nem são acessíveis naturalmente àqueles que deles fazem uso: eles são fundamentais, como melhor veremos adiante, apenas na medida em que são objeto dos correspondentes direitos sociais à sobrevivência.

\section{Os bens personalíssimos}

Os bens personalíssimos, como referido, formam a classe dos bens fundamentais mais estreitamente ligada aos direitos vitais da pessoa. O princípio da sua indisponibilidade, consequente ao valor da pessoa, possui a forma de uma proibição: “os atos de disposição do próprio corpo”, estabelece o já recordado artigo 5 do código civil, “são proibidos quando ocasionam uma diminuição permanente da integridade física, ou bem quando são contrários à lei, à ordem pública ou aos bons costumes”. $\mathrm{O}$ problema da sua garantia tem se manifestado, sobretudo com o desenvolvimento da tecnologia médica e cirúrgica, que tornou possível o transplante e em consequência a alienação e a utilização por parte de outros. Daí a proibição absoluta de qualquer violação deles, tanto mais necessária e relevante - para a tutela da integridade da pessoa e contra 
o drama do tráfico de órgãos - quanto mais fácil, tecnicamente é a sua desobediência.

O limite imposto à autonomia privada sobre os bens personalíssimos reflete, evidentemente, uma forma de paternalismo. Mas é o próprio paternalismo o que está à base da indisponibilidade dos direitos fundamentais: tais bens são subtraídos ao poder de disposição de seus possuidores justamente para protegê-los da sua alienação e, portanto, da sua redução a bens patrimoniais e da consequente regressão à lei do mais forte. Se, de fato, os titulares de tais direitos tivessem o poder de dispô-los conjuntamente com os bens disponíveis - por exemplo, vendendo a sua liberdade ou partes do seu corpo, ou tornando-se escravos - tais direitos e tais bens deixariam de ser universais e, portanto, fundamentais, e tornarse-iam patrimoniais. E se produziria uma insolúvel aporia: um tal poder de autodeterminação civil, enquanto absoluto e ilimitado, comportaria não diversamente de um poder de autodeterminação política igualmente ilimitado - também a disponibilidade dos próprios direitos de autonomia, com o consequente colapso da própria autodeterminação e, reflexamente, do inteiro edifício jurídico das liberdades civis.

Por trás dessas concepções ditas libertárias, há na realidade uma extensão indevida do léxico proprietário que corre sempre o risco de ser o veículo de uma desviante confusão entre direito real de propriedade, logo singular (excludendi alius) e disponível, e direitos fundamentais, enquanto tais universais (omnium) e indisponíveis, como são, por um lado, o direito civil de alienar direitos reais de propriedade e, por outro, o direito à saúde e à integridade pessoal. O risco é estender-se o conceito de "propriedade" até o seu uso indiscriminado, enquanto substantivo do adjetivo possessivo "próprio" também no tema de identidade pessoal e de relações familiares, afetivas, de trabalho e similares. Como já relevei várias vezes, a origem desta expansão invasiva do léxico proprietário e da confusão entre propriedade, liberdade e identidade pessoal, ${ }^{24}$ remonta

24 Veja-se Principia iuris cit., I, §§ 1.6 e 10.10; II, §§ 14.14-14-21. Remeto, outrossim, aos meus Tre concetti di libertà, in "Democrazia e dirito", 2001, p. 169-185; Proprietà e libertà, in "Parolecchiave”, n. 30, 2003, Proprietà, p. 13-29; Per um costituzionalismo di diritto privato, in "Rivista critica del diritto privato", anno XXII, n. 1, marzo 2004, p. 11-24; Diritto civile e principio di legalità, in Il diritto civile oggi. Compiti scientifici e 
a John Locke: “cada um”, escreve Locke, “tem a propriedade da própria pessoa”, inclusive, portanto “aquilo que lhe é próprio”. ${ }^{25}$ Fala-se, assim, de propriedade do "próprio” corpo, de propriedade do "próprio” trabalho, de propriedade dos "próprios” direitos e talvez dos "próprios” filhos ou do "próprio” cônjuge ${ }^{26}$ ou similares.

Pessoas e coisas são, no entanto, temas diferentes, aos quais não se pode associar os mesmos predicados. E mais: como afirma a máxima kantiana, segundo a qual nenhuma pessoa pode ser tratada como uma coisa, ${ }^{27}$ essas são figuras entre si contrárias e incompatíveis. ${ }^{28}$ Ao corpo das pessoas não é, portanto, aplicável o léxico proprietário. A propriedade diz respeito de fato às relações com as coisas; enquanto o corpo humano e seus órgãos não são coisas, como tais possíveis objetos de propriedade,

didattici del civilista, Edizioni Scientifiche Italiane, Napoli 2006, p. 81-91; Contra los poderes salvajes del mercado: para un constitucionalismo de derecho privado (2001), agora em Democracia y garantismo, aos cuidados de M. Carbonell, Editorial Trotta, Madrid 2008, p. 293-302.

25 É a célèbre passagem de J. Locke, § 27 (1968, p. 260-261).

26 Recorde-se a desconcertante passagem de Kant, flagrantemente em contraste com as suas máximas da moral recolhida na nota que segue: “Quando io dico: 'Mia moglie, la mia donna', ciò significa un rapporto particolare, vale a dire un rapporto giuridico del possessore con un oggetto (anche se questo è una persona) come una cosa. Il possesso (fisico) è dunque la condizione della possibilità dell'uso (manipulatio) di un oggetto come di una cosa, quantunque questo oggetto sotto un altro rapporto debba essere trattato nello stesso tempo come una persona” (Principi metafisici della dottrina del diritto (1797), parte II, sez.I, § 47, in Scritti politici e di filosofia della storia e del diritto, trad.it. di G.Vidari, aos cuidados de N. Bobbio, L. Firpo e V. Mathieu, Utet, Torino 1965, Parte II, Appendice, § 2, p. 551, nota). Recorde-se também, de Kant, as teses sobre a inferioridade da mulher (op. cit., Parte I, §§ 24-27, p. 459-462, em particular p. 461).

27 “'L'uomo non deve mai essere trattato come un puro mezzo al servizio dei fini di un altro ed essere confuso con gli oggetti del diritto reale” (KANT, 1970, p. 164). A mesma máxima foi expressa por C. Beccaria, Dei delitti e delle pene, ed. di Livorno del 1766, aos cuidados de F.Venturi, Einaudi, Torino 1981, § XX, p. 50: "Non vi è libertà ogni qual volta le leggi permettono che in alcuni eventi l'uomo cessi di esser persona e diventi cosa".

28 Expressei esta incompatibilidade em Principia iuris cit., I, p. 92 e 181, com o postulado P5: "I soggetti hanno uno status in forza del quale non sono oggetti”. Com este postulado, entre outros, tornam-se explicitamente preclusas as ambiguidades sintáticas geradas pelo uso das mesmas palavras para denotar gêneros de temas diversos (id, p. 102-103). 
mas partes integrantes da pessoa e da sua identidade física e psíquica: são aquilo que eles são e não já aquilo que eles têm. O "meu” corpo, em suma, não designa um objeto de minha propriedade, mas minha identidade, não menos do que o "meu” pensamento ou a "minha” mente, e é, portanto, o mesmo que estes configurados como bem fundamental: inviolável, inalienável, intangível.

\section{Os bens comuns: por um domínio público planetário}

Os bens comuns (common goods) são os bens fundamentais aos quais são majoritariamente voltadas, embora em medida totalmente inadequada, a atenção da doutrina jurídica e a reflexão teórico-política. A noção, introduzida no léxico jurídico somente em tempos recentes, tornou-se um tema de interesse e de mobilização política como sempre acontece quando se trata de bens ou direitos fundamentais, para exprimir uma reivindicação direta para pôr termo a uma específica violação: o desfrute dos recursos naturais por parte dos países mais ricos e, sobretudo, a devastação do planeta provocada pelo desenvolvimento industrial. É desta devastação e do perigo de uma destruição irreversível dos bens e dos recursos vitais para o futuro do gênero humano que nasceu a temática dos bens comuns: tais são os bens de todos - aqueles que os romanos chamavam de res communes omnium - como o ar, o clima, a água, as órbitas dos satélites, as bandas do éter, os recursos minerais das profundezas marinhas, a assim chamada biodiversidade e todos os outros bens do patrimônio ecológico da humanidade.

Com respeito aos bens personalíssimos, os bens comuns apresentam características em parte similares e em parte opostas. Tanto uns quanto outros, como se viu, são bens naturais, cujo valor vital justifica a subtração à apropriação privada e a garantia a todos enquanto pessoas, como objeto de direitos fundamentais de imunidade. Mas, enquanto os bens personalíssimos são universais no sentido de que pertencem a cada ser humano e são acessíveis unicamente a ele com exclusão dos outros enquanto partes integrantes da sua pessoa, os bens comuns o são no sentido oposto de que pertencem e deve ser garantida a sua acessibilidade 
a todos pro indiviso, tanto assim que são configurados, em muitos tratados internacionais, como "patrimônio comum da humanidade", ${ }^{29}$ isto é, de um sujeito que inclui também as futuras gerações.

É com referência aos bens comuns onde mais claramente se manifesta a inadequação do uso exclusivo da linguagem de direitos fundamentais. Embora a proteção de tais bens seja um interesse vital de todos, de tais interesses não são conscientes as pessoas singulares, embora titulares dos respectivos direitos fundamentais. Quando se envenena o ar de uma cidade, ou se coloca em risco uma praia, ou se abate uma floresta, os habitantes do lugar não pensam estar sendo privados de uma propriedade comum, mas consideram-se apenas usuários, consumidores ou possíveis beneficiários de futuros loteamentos. Ainda menos vital e pela maioria das pessoas totalmente irrelevante e até incompreensível é, além disso, o interesse pela proteção do clima e dos equilíbrios ecológicos, ${ }^{30}$

29 Recorde-se o Tratado sobre os espaços estratosféricos do 27/1/1997, que qualifica tais espaços como "apanágio de toda a humanidade”, impondo-se a “ utilização para o bem e no interesse de todos os países, seja qual for o estágio de seu desenvolvimento econômico ou científico” (art. 1) e proibindo “a apropriação nacional através de proclamações de soberania ou atos de utilização ou ocupação ou outros meios” (art. 2). Recorde-se ainda a Convenção das Nações Unidas sobre o direito do mar de 10/12/1982, que afirma que “a área (de alto mar) e seus recursos" - sejam eles "sólidos, líquidos ou gasosos, in situ” ou "sobre os fundos marinhos ou no seu subsolo" (art. 133) - "são patrimônio comum da humanidade” (art. 136), veda “a apropriação” por parte de qualquer "Estado ou pessoa física ou jurídica” (art.136, 1) e estabelece que " todos os direitos sobre os recursos da área são conferidos a toda a humanidade”, que “estes recursos são inalienáveis” (art. 136, срv), que “os Estados contraentes são solidariamente responsáveis” pelos danos provocados "pelas empresas estatais ou pessoas físicas ou jurídicas que possuam a nacionalidade” (artigo 139), que "as atividades na área são conduzidas em benefício de toda a humanidade” e que "das vantagens econômicas derivadas” deve ser "assegurada a igual repartição... em base não discriminatória [...] levando particularmente em conta os interesses e as necessidades dos Estados em via de desenvolvimento" (artigos 140 e $160, f$ e $i$ ). Sobre a noção de "patrimônio comum da humanidade” vejam-se as diversas acepções em J. M. Pureza (2002); AA.VV (2002).

30 Estudos recentes têm demonstrado que a grande maioria da população mundial, sobretudo nos países ricos, não considera as mudanças climáticas um problema relevante e que, além disso, grande parte daqueles que o consideram um problema entendem que a humanidade não será capaz de fazer nada para afrontá-lo (Human Development. Report 2007/2008. Fighting climate change. Human solidarity in a divided world, tr.it. Lo sviluppo 
que diz respeito até mesmo às futuras gerações cujos direitos são futuros e que somente podem ser resguardados protegendo-se os bens comuns, deixando-lhes de herança um planeta habitável.

Manifesta-se neste caso uma grave aporia da democracia política. A ameaça mais grave ao futuro da humanidade é representada pelos efeitos desastrosos provocados pelo crescente aquecimento global gerado pelas emissões de gás estufa: o encolhimento das calotas de gelo na Groenlândia e na Antártida, a consequente elevação do nível dos mares, a acidificação dos oceanos, a redução da biodiversidade, a devastação das florestas e a desertificação de áreas crescentes do planeta, as mudanças nos fluxos da corrente do Golfo. ${ }^{31}$ Mas esta ameaça é totalmente ignorada pela opinião pública mundial e consequentemente pelos governos nacionais; portanto, não entra, senão marginalmente, em sua agenda política inteiramente ancorada nos restritos horizontes nacionais desenhados pelas metas eleitorais. Já foi calculado que o mundo tem menos de dez anos para poder alterar o curso desta crise antes que ela se torne irreversível. ${ }^{32}$ Naturalmente, trata-se de previsões incertas. Mas a incerteza diz respeito apenas ao prazo dos desastres, e não à sua futura ocorrência, certamente se não se intervém a tempo.

As mudanças climáticas produziram devastações e catástrofes, ${ }^{33}$ e muitas dessas alterações foram provocadas quase inteiramente pelas

umano. Rapporto 2007-2008. Resistere al cambiamento climatico, (ROSENBERG; SELLIER, 2007, p. 95-96).

31 Foi calculado que desde o início da era industrial os depósitos de CO2 na atmosfera aumentaram um terço; que nos últimos 100 anos, por causa do efeito estufa, a temperatura média global aumentou 0,7 graus, e que este incremento se desenvolve sempre mais rapidamente; que, afinal, um aumento superior aos dois graus provocaria eventos catastróficos e irreversíveis para as gerações futuras (id, p. 51-56 e 27-28). Sobre estas catástrofes, veja-se, infra, as notas 34-36. Precisamente, as concentrações de CO2 na atmosfera que eram de 296 ppm em 1900, de 313 em 1950, de 326 em 1970 e de 354 em 1990, ascenderam a 385 em 2008 (www. Carbon Dioxide Information Analysis center): uma cifra próxima ao patamar de 450, julgado este como nível de alerta (Rapporto 20072008 cit., p. 27 e 39).

32 Idem, p. 21 e 47.

33 Nos últimos cinquenta anos, a temperatura média anual na área compreendida entre o Alasca e a Sibéria aumentou 3,6 graus; nos últimos trinta anos a camada de neve diminuiu 
nações ricas. ${ }^{34}$ Existe a capacidade de enfrentá-las, regulando-se os termostatos e aumentando os aprovisionamentos. Todavia, isso tem golpeado de maneira incomparavelmente mais grave as populações mais pobres, como aquelas da África e das zonas costeiras. ${ }^{35}$ Secas, avalanches, furacões e ciclones tropicais têm atingido os países mais pobres, aqueles que vivem da agricultura, provocando desertificações e inundações, reduzindo a disponibilidade hídrica e alimentar, destruindo as frágeis habitações e comprometendo irreversivelmente a capacidade produtiva e a possibilidade de desenvolvimento. ${ }^{36}$ É claro, todos esses danos estão destinados a agravar-se dia após dia se nada for feito para minimizá-los. ${ }^{37}$

10\% e a calota de gelo um 15-20\%; quase uma espécie de mamífero em cada quatro está em extinção (Idem, p. 136-137).

${ }^{34}$ Não obstante ao rápido crescimento econômico e industrial da China e da Índia, um habitante dos Estados Unidos possui ainda "um impacto ecológico" cinco vezes superior ao de um chinês e quinze vezes superior ao de um indiano; o impacto ecológico de um habitante do Canadá é duzentas vezes superior ao de um habitante da Etiópia (Idem, p. 28). Confiram-se os dados comparativos mais específicos, idem, p. 66-69. Por outro lado, em termos quantitativos, a maior quantidade de emissão é provocada pela China que produz anualmente 1 bilhão e 802 milhões de toneladas de CO2. Seguem-lhe os Estados Unidos, com 1 bilhão e 886 milhões de toneladas de CO2, a Rússia com 432 milhões, a Índia com 430 milhões, o Japão com 337, a Alemanha com 210, o Canadá e a GrãBretanha com 145, a Coreia do Sul e o Irã com 130, o México e a Itália com 121, a África do Sul com 118, a Arábia com 115, a Indonésia com 114, a Austrália com 103, a Grécia com 98, o Brasil com 96 e a Espanha com 95 (www.Carbon Dioxide Information Analysis Center).

${ }^{35}$ Entre 2000 e 2004 cerca de 262 milhões de pessoas ao ano, das quais 98\% nos países em desenvolvimento, foram atingidos por catástrofes climáticas; e enquanto nos países da OCDE estas catástrofes atingiram um habitante em cada 1.500, nos países pobres, tem sido atingida uma pessoa em cada 19 (Rapporto 2007-2008 cit, p. 29, 54, 105). Sobre as várias catástrofes que atingem e atingirão as populações pobres veja-se entre outros Id., p. 113-142.

${ }^{36}$ Idem, p. 133-136.

37 Até o ano de 2060, as áreas da África subsaariana atingidas pela seca poderão ampliarse em até 90 milhões de hectares; até 2080 o número de pessoas que sofrem de escassez de água poderá ultrapassar 1,8 bilhões; sete grandes sistemas fluviais asiáticos aumentarão, pelo encolhimento dos glaciares do Himalaia; primeiro um aumento, mas depois uma drástica redução dos fluxos hídricos (Idem, p. 30). Até o final deste século, prevê-se um aumento dos níveis dos mares entre 20 e 60 centímetros (Idem, p. 62), que provocaria a 
Daí a necessidade de uma nova dimensão do constitucionalismo e do garantismo: um constitucionalismo e um garantismo a longo prazo, além de global, para além da lógica individualista dos direitos e da miopia e do estreito localismo da política das democracias nacionais. $\mathrm{Na}$ nossa tradição, de resto, o único poder que, pela via única dos direitos, foi tematizado como objeto de limites e vínculos legais tem sido o poder político estatal: “estado de direito”, não por acaso, é a expressão que designa no nosso léxico jurídico à sujeição do poder ao direito. Restam assim excluídos dois tipos de poderes, ambos não estatais, que são justamente aqueles principais responsáveis pelas catástrofes ecológicas e para cujo confronto requer-se a criação de um constitucionalismo e de um garantismo dos bens comuns: de um lado os poderes econômicos privados, tradicionalmente rotulados como liberdades; de outro, os poderes extra ou supraestatais, políticos ou econômicos, que se desenvolvem fora das fronteiras estatais no mundo globalizado.

É, em primeiro lugar, necessário - sob a base do reconhecimento do caráter de poderes privados, mais do que de liberdades dos direitos de iniciativa e de autonomia empresarial ${ }^{38}$ - o desenvolvimento, em garantia dos bens comuns, de um constitucionalismo de direito privado, isto é, de um sistema constitucional de regras, de limites, de vínculos e de controles, supraordenado a tais poderes econômicos privados, além de sê-lo aos poderes políticos, e dirigido a disciplinar-lhes o exercício: de impedir, em particular, a emissão de substâncias tóxicas nocivas à saúde e ao ambiente, bem como a apropriação privada, a dissipação ou a destruição dos bens comuns, como o ar e a água de cuja defesa depende o futuro do planeta e a sobrevivência da humanidade. Para tal fim, requerse a construção de uma esfera pública enquanto esfera heterônoma com respeito aos direitos civis de autonomia e uma refundação do princípio de legalidade, em condições de disciplinar os poderes de outra maneira

inundação de vastas áreas do Egito, do Vietnam e de Bangladesh e colocaria em risco a sobrevivência dos estados insulares do Pacífico e do Caribe (Idem, p. 134-135).

38 Sobre a crítica da tradicional configuração liberal, de origem lockiana, dos direitos civis de autonomia privada como direitos de liberdade, mais do que como direitos-poderes cujo exercício incide sobre a esfera jurídica alheia, detive-me no trabalho citado na nota 23. 
selvagens do mercado e de proteger as gerações presentes e futuras dos danos irreversíveis provocados aos bens comuns pelo seu exercício.

É necessário, em segundo lugar, o desenvolvimento de um constitucionalismo de direito internacional. Mesmo porque as agressões aos bens comuns do ambiente - o aquecimento climático, a poluição do ar e dos mares, a redução da biodiversidade e a destruição de muitas espécies animais e vegetais - têm já assumido um caráter planetário, exigindo a introdução de normas, limites, vínculos, controles, funções e instituições de garantia por sua vez em nível planetário. Para tal fim, bem mais apropriada do que as técnicas de garantia experimentadas pelos direitos fundamentais, é a direta proteção normativa de tais bens como bens públicos. É esta, de resto, a garantia de muitos bens comuns adotada nos ordenamentos estatais: a sua qualificação, por obra de normas téticoconstitutivas, ${ }^{39}$ como bens públicos, ${ }^{40}$ como tais subtraídos à apropriação e à negociação privada e confiados à tutela da autoridade administrativa. ${ }^{41}$

39 No sentido ilustrado supra, na nota 11. Precisamente segundo a tese T 8.41 formulada em Principia iuris cit, I, §8.3 p. 426, são normas tético-constitutivas aquelas que dispõem imediatamente status.

${ }^{40}$ Recorde-se a norma tético-constitutiva dos "beni demaniale" ditada pelo artigo 822 do código civil italiano: "Appartengono allo Stato e fanno parte del demanio pubblico il lido del mare, la spiaggia, le rade e i porti; i fiumi, i torrenti, i laghi e le altre acque definite pubbliche dalle leggi in materia; le opere destinate alla difesa nazionale. Fanno parimenti parte del demanio pubblico, se appartengono allo Stato, le strade, le autostrade e le strade ferrate; gli aerodromi; gli acquedotti; gli immobili riconosciuti di interesse storico, archeologico e artistico, a norma delle leggi in materia; le raccolte dei musei, delle pinacoteche, degli archivi, delle biblioteche, e infine gli altri beni che sono dalla legge assoggettati al regime proprio del demanio pubblico". O artigo 43 da Constituição italiana estabelece outrossim que "a fini di utilità generale la legge può riservare originariamente o trasferire, mediante espropriazione e salvo indennizzo, allo Stato, ad enti pubblici o a comunità di lavoratori o di utenti determinate imprese o categorie di imprese che si riferiscano a servizi pubblici essenziali o a fonti di energia o a situazioni di monopolio ed abbiano carattere di preminente interesse generale".

${ }^{41}$ O artigo 823 do código civil estabelece: "I beni che fanno parte del demanio pubblico sono inalienabili e non possono formare oggetto di diritti a favore di terzi, se non nei modi e nei limiti stabiliti dalla legge che li riguardano. Spetta all'autorità amministrativa la tutela dei beni che fanno parte del demanio pubblico. Essa ha facoltà sia di procedere in via amministrativa, sia di valersi dei mezzi ordinari a difesa della proprietà e del possesso regolati dal codice". 
Mas é claro que o interesse geral expresso pela garantia dos bens comuns globais (global commons) não pode ser de nível estatal, mas sim de nível global, através da instituição de um domínio público planetário. Tais bens deveriam, em suma, ser declarados bens públicos planetários por uma carta internacional dos bens comuns e confiados à proteção de adequadas autoridades internacionais de garantia: em matéria de atmosfera, de águas potáveis, de biodiversidade e similares. ${ }^{42}$

Além disso, há outro problema: o energético, em parte análogo e, portanto, conexo ao dos bens comuns. Está previsto que, em poucos decênios, estarão exauridas as energias não renováveis, obtidas principalmente de recursos naturais de origem fóssil, como o gás, o carvão e sobretudo o petróleo, saqueados nos últimos decênios pelas grandes companhias do Ocidente sob o signo das dinâmicas desreguladas do mercado. Em poucos decênios, a humanidade destruiu um patrimônio energético acumulado em milhões de anos. E essa dissipação tem sido também a causa principal da poluição atmosférica e do aquecimento do planeta. A única alternativa ao colapso de toda a economia planetária e, ao mesmo tempo, à catástrofe climática, é, portanto, novamente, a construção de uma esfera pública internacional apta a impor reduções às emissões e limites aos desperdícios e, sobretudo, sustentar o custo dos investimentos necessários para a criação das instalações necessárias para a produção de energias limpas, como o sol, o vento e as marés.

Sob todos esses aspectos, os problemas gerados pela necessidade e pela urgência de proteger os bens comuns revelam uma interdependência ecológica que congrega todos os membros da família humana. É esta a grande e positiva novidade que esses problemas criaram. Para além de todas as diferenças políticas e culturais, das desigualdades econômicas e dos inumeráveis conflitos que atravessam e dividem a humanidade, a ameaça que hoje paira sobre os bens ecológicos adverte a todos de que

\footnotetext{
42 É o que fazem, limitando-se aos espaços estratosféricos e às águas do mar, as normas tético-constitutivas contidas nas duas convenções internacionais recordadas supra na nota 27: o Tratado sobre espaços estratosféricos de 1967 e a Convenção das Nações Unidas sobre direito do mar de 1982. Ademais, os artigos 156 ss. desta última Convenção instituem uma “Autoridade internacional dos solos marinhos” voltada à garantia secundária de tudo quanto nela é estabelecido.
} 
se trata de um patrimônio comum que nenhuma política nacional ou de liberalismo econômico poderá jamais confiscar ou privatizar: o planeta Terra, com seus mares e sua atmosfera, que todos compartilhamos e que é do interesse de todos preservar. Esta ameaça é, portanto, não apenas o problema político mais grave, que deverá ser afrontado urgentemente com opções radicais dirigidas a mitigar as mudanças climáticas criadas pelo desenvolvimento de modos de vida e de tecnologias produtivas com base em emissões de gases estufa e, ao mesmo tempo, estender aos países pobres as técnicas de proteção e de adaptação às mudanças desenvolvidas nos países ricos. ${ }^{43}$ Isto representa também uma oportunidade sem precedentes na história: a possibilidade de refundar a garantia da paz e dos direitos humanos sobre a base da necessária interdependência mundial gerada por tal ameaça. O desafio global lançado por esta ameaça impõe de fato uma política global baseada numa cooperação mundial da qual nenhuma potência poderá subtrair-se. E o desafio será vencido apenas se for criada uma esfera pública planetária à sua altura, com a garantia de um interesse público geral bem mais amplo do que os diversos e contrapostos interesses públicos nacionais, porque identificada com o interesse comum de toda a humanidade.

\section{Os bens sociais}

Denominei de "bens sociais” aqueles bens - como a água potável, os medicamentos essenciais e os produtos necessários para a alimentação básica - que são objeto dos direitos sociais, isto é, daqueles direitos fundamentais que consistem em prestações, como a alimentação básica e a assistência sanitária. ${ }^{44}$ Estes bens coincidem, em grande parte, com

\footnotetext{
43 Às análises desta dúplice resposta ao desafio do aquecimento global - as variadas formas de redução das emissões de gases estufa, antes de tudo o emprego de energias renováveis, capazes de mitigar as mudanças climáticas e, de outro lado, as diversas estratégias de defesa e de adaptação a tais mudanças - são dedicados os capítulos III e IV, p. 143-246, do Rapporto 2007-2008 cit.

44 In Principia iuris cit., $\S \S 11,10$ e 11.4, p. 778 e 742, defini os bens sociais como os bens fundamentais que são objeto de direitos sociais (D11.31), isto é, os direitos fundamentais a prestações positivas (D11.10).
} 
os bens fundamentais que não são tais por natureza, como o são os bens personalíssimos e os comuns, mas são duplamente artificiais: no sentido de que são produzidos ou distribuídos pelo homem, e no sentido de que são convencionados como tais, isto é, como bens vitais que devem ser juridicamente acessíveis a todos, mesmo porque, por causa do estado de indigência, não são de fato naturalmente acessíveis a todos. Sob este último aspecto, tais bens são "fundamentais", em sentido não objetivo, mas subjetivo: para quem não está em condições de adquiri-los como bens patrimoniais. O são, saliento, na medida em que são objeto dos direitos sociais à sobrevivência estipulados nas cartas constitucionais e internacionais.

A estipulação desses direitos como direitos fundamentais à sobrevivência é um fenômeno relativamente recente, afirmados nas constituições do século passado graças à mudança de sentido do mais importante dos direitos humanos: o direito à vida. Na tradição liberal, este direito foi concebido unicamente como um direito de imunidade, isto é, de não ser morto. A sobrevivência era de fato concebida pela ideologia liberal, como um fenômeno natural, garantido a todos pela relação direta do homem com a natureza e, portanto, simplesmente, pela sua livre iniciativa e vontade: resumindo, segundo o paradigma lockeano, da "entidade do trabalho do homem", sobre cuja base "a medida da propriedade é pela natureza bem estabelecida”. ${ }^{45}$ Cada um, segundo esta concepção, tem a possibilidade de sobreviver desde que o queira: porque pode sempre trabalhar, se apenas o quiser, dado que haverá sempre campos nos quais pode tornar a viver dos produtos da terra e, no pior dos casos, as terras incultas da América para as quais emigrar. ${ }^{46}$

\footnotetext{
45 J. Locke, cap.V, § 36 (1968, p. 266).

46 Idem, § 33, p.264: “Né questa appropriazione di una porzione di terra in base alla coltivazione di essa torna a pregiudizio per altri, poiché ne rimane sempre abbastanza e altrettanto buona, e più di quanta possa servire a chi ne è ancora sprovvisto"; Idem, § 36, p. 266: "La stessa misura può continuare ad ammettersi senza pregiudizio di alcuno per quanto il mondo appaia popolato" quando "un uomo o una famiglia... si stabilisca in qualche parte interna e desterta dell'America”. É sobre esta relação entre propriedade, trabalho e vontade individual que se funda grande parte da legitimação ideológica do capitalismo.
} 
Hoje, esse pressuposto, se é que alguma vez teve fundamento, está seguramente diminuído. No mundo hodierno, como provam o desemprego endêmico que aflige as nossas sociedades e as migrações em massa repelidas nas nossas fronteiras, rompeu-se irremediavelmente a relação entre sobrevivência, trabalho, e iniciativa individual autônoma. Sobreviver, portanto, é sempre menos um fato natural e sempre mais um fato social. Daí, na ausência de garantias sociais de sobrevivência, as desigualdades crescentes nos países ricos e a miséria apavorante na qual vivem e morrem todo ano milhões de seres humanos, não obstante o enorme aumento da riqueza produzida sobre o planeta. ${ }^{47} \mathrm{E}$, em consequência, a mudança no alcance do "direito à vida” estabelecida pelo art. 3 da Declaração Universal dos Direitos Humanos: a vida encontrase hoje ameaçada pela falta dos bens sociais - a água, o alimento e os medicamentos essenciais - em medida incomparavelmente maior do que pela possibilidade da sua supressão violenta por obra da criminalidade e até das guerras. Por isso, o clássico direito à vida, cuja tutela foi assumida desde Thomas Hobbes como a razão de ser do direito e das instituições políticas não pode hoje deixar de incluir, ao lado do direito de não ser morto, também o direito a sobreviver, e portanto a fruição dos bens necessários para tal fim.

São três as grandes, terríveis emergências globais que estão provocando dezenas de milhões de mortos a cada ano e tornam necessária

47 Segundo Human Development Report 1999, trad. it. Rapporto (ROSENBERG; SELLIER, 1999), La globalizzazione, a diferença de renda entre a quinta parte da população dos países mais pobres e a quinta parte daquela dos países mais ricos do planeta, que era de 1 a 3 em 1820, de 1 a 11 em 1913, de 1 a 30 em 1960, de 1 a 60 em 1960 tornou-se de 1 a 74 em 1997 (p. 55 e 19). De outro lado, menos de 300 bilionários (em dólares) possuem mais riqueza que a metade da população mundial, ou seja, de 3 bilhões de pessoas; o patrimônio das três pessoas mais ricas do mundo supera a soma do produto nacional bruto de todos os países menos desenvolvidos e de seus 600 milhões de habitantes (Idem, p. 55 e 19); além disso, um bilhão de pessoas não tem acesso à água e à alimentação básica, o que provoca 15 milhões de mortes por ano, e mais de 17 milhões de pessoas morrem todo o ano pela falta dos medicamentos que os curariam. Segundo o Rapporto 2007-2008 cit., p.49-50, cerca de um bilhão de pessoas vivem com menos de um dólar ao dia e 2,6 bilhões, correspondentes a $40 \%$ da população mundial, vivem com menos de dois dólares ao dia, isto é, com uma renda conjunta igual a 5\% da renda global; enquanto três quartos da renda mundial são recebidas por $20 \%$ das pessoas mais ricas. 
e urgente a qualificação desses bens como fundamentais: a fome, a sede e as doenças curáveis mas não curadas. A garantia do acesso universal a tais bens - a água potável, os alimentos básicos e os medicamentos essenciais - é possível apenas através da sua subtração à lógica do mercado e a atribuição à esfera pública da sua distribuição e, se necessário, da sua produção. Diversamente dos bens personalíssimos e dos bens comuns, como já referi, estes bens podem muito bem ser também patrimoniais, mas apenas na quantia excedente ao mínimo vital. Por causa da sua escassez, deve ser reconhecido o seu caráter público e fundamental na medida necessária para satisfazer os direitos sociais à subsistência. E esse reconhecimento é do interesse de todos, e não somente das populações pobres. O constitucionalismo dos bens sociais, não diferentemente daquele dos bens comuns, também é um constitucionalismo a longo prazo: como a experiência dos países ricos ensina, o investimento em despesas sociais - a instrução, a saúde, a subsistência - é o primeiro investimento produtivo, dado que realiza, com a garantia dos mínimos vitais, a primeira condição da produtividade tanto individual como coletiva e portanto do desenvolvimento econômico. Em suma, se é verdade que os direitos sociais custam, ${ }^{48}$ o custo da falta da sua satisfação é muito maior, condenando bilhões de seres humanos à indigência e ao desenvolvimento e sendo fonte inevitável de migrações de massa e de conflito. ${ }^{49}$

A primeira emergência dramática é aquela do acesso à água, objeto daquele corolário do direito à vida que é precisamente o direito à subsistência. A água potável não é mais, de fato, um bem natural, nem muito menos um bem comum naturalmente acessível a todos. Mais de um bilhão de pessoas não dispõem da possibilidade de aceder a ela; e por esta impossibilidade milhões de pessoas morrem todo ano. A água, de fato, tornou-se um bem escasso por dois motivos: pelas agressões ao patrimônio florestal, que provocam todo ano a devastação de milhões de hectares, muitos dos quais viram deserto; pela poluição das nascentes, dos rios e dos aquíferos, provocados pelas atividades industriais desreguladas; e pela

\footnotetext{
48 Holmes e Sunstein (1999), trad.it., Il costo dei diritti. Perché la libertà dipende dalle tasse, Il Mulino, Bologna 2000.

49 Remeto, sobre a relação entre direitos sociais e economia, à Principia iuris cit., II, § 13.13, p. 67-71.
} 
massiva privatização, enfim, dos recursos hídricos que paradoxalmente são reduzidos a bens patrimoniais no mesmo momento em que se exige, pela sua escassez, a sua garantia como bens fundamentais. Esta garantia somente pode consistir na transformação da água potável num bem público, submetido a um tríplice estatuto: a obrigação da sua distribuição gratuita a todos na medida necessária para satisfazer os mínimos vitais (calculada em pelo menos 40 ou 50 litros diários por pessoa); a proibição da sua destruição e do seu consumo além de um determinado limite máximo; a taxação, enfim, em bases progressivas dos consumos excedentes do limite mínimo, mas inferiores ao limite máximo..$^{50} \mathrm{E}$ para tal fim, é evidente que se requer a instituição, a nível internacional, de uma Autoridade independente para as águas potáveis voltada à proteção dos recursos hídricos do planeta, ao controle de seu desperdício e de sua poluição, à taxação dos consumos excedentes aos mínimos vitais e, sobretudo, à distribuição capilar para todos da água potável através da instalação no mundo inteiro de poços, aquedutos, fontes públicas, serviços hídricos e sistemas públicos de irrigação.

Um discurso análogo pode ser feito para o alimento, que na medida do mínimo vital forma o objeto a par da água, do direito a "uma alimentação adequada” estabelecido pelo art. 11 do Pacto sobre direitos econômicos, sociais e culturais de $1966 .{ }^{51}$ Hoje, mais de um bilhão de pessoas padece de fome. ${ }^{52}$ Uma política alimentar dirigida a afrontar esta catástrofe deveria em primeiro lugar proteger e subvencionar a agricultura dos países pobres, favorecendo-lhes o desenvolvimento,

50 São os três estatutos propostos pelo Manifesto italiano per il contratto mondiale dell'acqua, sobre o qual confira Petrella (2001, p. 137-138). Sobre o problema da água vejase também Nebbia (1999); De Villiers (2000); Shiva (2002), trad.it., Le guerre dell'acqua, Feltrinelli, Milano 2003; AA.VV. (2002); o fascículo Acqua da revista Parolechiave, 27, 2002; Petrella (2003), com prefácio de Luciano Gallino; Zolo (2005, 1, p. 125-142); Lucarelli; Marotta (2006); Molinari (2006, n.2/3, p.197-210).

51 Sobre os problemas da fome no mundo, cf. Barbina (2001); Ziegler (2002); Pisarello (2003).

52 Calcula-se que, por causa da fome e da desnutrição, um $28 \%$ das crianças nos países em desenvolvimento está abaixo do peso ou sofre de nanismo, e que cerca de 10 milhões de crianças morrem todo o ano antes de completar 5 anos (Rapporto 20072008, p. 49-50). 
invertendo as atuais políticas do Fundo Monetário Internacional, que, pelo contrário, consentem o protecionismo agrícola e as subvenções estatais para a agricultura dos países ricos e impõem a abertura dos mercados aos países pobres. Para a proteção da agricultura desses países, seria necessário disciplinar a exportação, visando à produção dos alimentos chamados "ogm” (organismos geneticamente modificados), de sementes não naturalmente reproduzíveis, para impedir que estes danifiquem a fertilidade dos terrenos e venham a provocar a dependência da agricultura dos países pobres em relação aos países ricos exportadores. Mas, sobretudo, deveria ser garantida a instituição de preços políticos dos produtos alimentares para os países pobres e, se necessário, a produção e a distribuição gratuita a tais países dos alimentos básicos. Finalmente, uma Autoridade internacional de garantia como é atualmente a FAO (Food and Agriculture Organization), deveria ser dotada de um orçamento bem superior ao atual, em condições de financiar as garantias supraindicadas e, em particular, a aquisição ou a produção e a distribuição gratuita dos alimentos em favor das populações famintas. Trata-se, com efeito, ainda nesses casos, de bens patrimoniais na medida em que excedam, para cada um, o mínimo vital, mas de bens sociais na medida inferior a tal mínimo, necessária à satisfação do direito fundamental à subsistência.

A mesma coisa pode-se dizer enfim para aqueles bens fundamentais que são os medicamentos essenciais, produzidos pelo desenvolvimento da pesquisa científica e pela tecnologia farmacêutica. Em 1977, a OMS (Organização Mundial da Saúde) propôs, para estes medicamentos, a seguinte definição: “definem-se como 'medicamentos essenciais' aqueles que satisfazem as necessidades sanitárias da maior parte da população e que devem, portanto estar disponíveis a todo momento em quantidade suficiente e na forma farmacêutica apropriada”. A lista que originariamente era formada por pouco mais de 200 medicamentos e que em 1997, continha pouco menos de $300^{53}$ - implica a obrigação do fornecimento gratuito de tais medicamentos, e exprime, portanto, um projeto mínimo de igualdade no direito à saúde, que infelizmente tem sido dramaticamente insatisfeito. Muitos destes medicamentos,

53 Tognoni (1998, p. 116-122). 
como as vacinas contra as doenças infecciosas, não custam quase nada, mas não são distribuídos e em alguns casos nem mesmo produzidos por falta de demanda nos países ricos. Outros - cerca de 15\%, entre os quais os medicamentos contra a AIDS e a meningite -são patenteados e portanto muito onerosos para os países pobres. ${ }^{54} \mathrm{O}$ resultado desta gigantesca omissão de socorro são mais de 15 milhões de mortos por ano, ${ }^{55}$ vítimas, portanto, mais do que de doenças, das leis do mercado, ${ }^{56}$

$54 \mathrm{O}$ acordo sobre a propriedade intelectual Trips (Trade-Related Aspects of Intellectual Property Rights) promovido pela Organização Mundial do Comércio, posto em vigor em janeiro de 1996, em busca do objetivo de impedir o comércio de medicamentos "não conformes" ou "falsificados”, generaliza a patente sobre medicamentos e, portanto a proibição de aquisição no exterior de medicamentos similares por 20 anos. A consequência deste acordo é que, por exemplo, o medicamento anti-AIDS (patente Pfizer) custa no Quênia 10,5 dólares, enquanto na Tailândia o correspondente medicamento "genérico" custa 0,60 dólares (e o AZT, outro medicamento anti-AIDS, custa na Tailândia 0,37 dólares). Em geral, os custos de produção destes medicamentos - vendidos a um preço até 40 vezes superiores àqueles do correspondente medicamento "genérico" e frequentemente até superior ao preço que é vendido nos países ricos - são baixíssimos, próximos a zero (Accesso ai farmaci: la malattia del profitto, dossiê de "Medici senza frontiere", organizado por Correggia (2002, p. 12-13).

55 Seis doenças infecciosas estão na origem desta hecatombe: 4 milhões de mortos a cada ano por infecções das vias respiratórias; 3,9 milhões por poliomielite; 1,670 milhões por tuberculose, 1,086 milhões por malária; 2,473 milhões por doenças intestinais; 1,554 milhões pelo sarampo e outras doenças infecciosas previsíveis; 3 milhões por AIDS/HIV (Acesso aos medicamentos, cit. p. 6, fonte: Relatório OMS, 2000). 95\% dos mortos por AIDS são provenientes dos países pobres e 79\% apenas na África subsaariana (id, p, 7), onde ocorrem também 90\% das mortes por malária (id, p. 8). A África, onde ocorre maior o número de mortes por doenças não tratadas, absorve apenas 1,1\% das vendas globais de medicamentos (id, p. 5). Segundo o Rapporto 2007-2008 cit, p. 50 e 140, ainda em 2004, os doentes de AIDS eram 40 milhões, com 3 milhões de falecimentos, e 350-500 milhões foram os casos de malária, com 1,2 milhões de mortos, dos quais $80 \%$ entre as crianças africanas.

56 Para aquelas doenças há tempo debeladas nos países ricos, não há investimentos em pesquisa de novos medicamentos. 90\% do dinheiro investido na pesquisa farmacêutica tem por objeto medicamentos de luxo - contra a obesidade, as rugas, a esterilidade ou a impotência - que interessam a $10 \%$ da população mundial. Somente $0,2 \%$ diz respeito à poliomielite, a disenteria ou a tuberculose, praticamente desaparecidas nos países ocidentais. Segundo a OMS, um investimento global e um bilhão de dólares, equivalente ao lucro de uma companhia, em 1999, por sua pílula anti-impotência, iria diminuir pela metade o milhão de mortes anuais provocadas pela malária (Acesso ai farmaci, op. cit., p. 5). 
claramente incompatíveis com o direito à saúde, cuja satisfação requer a distribuição gratuita a todos, através de postos farmacêuticos públicos, de todos os medicamentos essenciais, de acordo com seu caráter precisamente de bens sociais fundamentais. Para tal fim, a OMS deveria ser provida de fundos adequados e de efetivas funções de garantia em grau de promover todas as atividades necessárias a satisfazer o direito à saúde: o financiamento público, internacional mais do que estatal, da pesquisa, sobretudo de doenças infecciosas e tropicais; a produção pública, por parte da OMS e o fornecimento gratuito aos países pobres de todos os medicamentos essenciais não mais produzidos por razões de mercado, a começar pelas vacinas, na medida exigida pelas necessidades de cura e de prevenção; a exclusão ao patenteamento dos medicamentos essenciais, cuja produção e distribuição, incluídas as despesas com a pesquisa, deveriam ser confiadas à esfera pública, ou a aquisição das patentes por parte da OMS, ou ainda, no mínimo, a drástica redução de seu prazo de duração e a autorização aos países pobres para produzir a baixo custo os respectivos medicamentos genéricos; o controle público sobre os preços internacionais dos medicamentos e a previsão de preços políticos para os países pobres; a imposição às empresas farmacêuticas privadas, acompanhada talvez de incentivos e abatimentos fiscais, de distribuir gratuitamente aos governos dos países mais pobres ou aos seus hospitais uma parte de seus produtos.

\section{Conclusões}

As diversas garantias suprailustradas dos bens fundamentais correspondem a uma dimensão nova e afinal inderrogável da democracia e do constitucionalismo. Totalmente nova porque conexa aos recentes e crescentes desenvolvimentos da indústria e das tecnologias; e, no entanto, inadiável é a identificação de rígidos limites à lógica do mercado, para garantia dos bens personalíssimos e dos comuns, que envolve os dramáticos e nunca simples problemas da bioética e da ecologia. Estes limites se concentram de fato em limites ao desenvolvimento, pela tutela tanto das gerações presentes quanto das futuras. E comportam, pela primeira vez 
na história, um conflito entre direito e tecnologia, ou pior, entre direito e ciência, que contradiz e conduz a repensar a ideia, enraizada na cultura ocidental, do caráter progressivo do desenvolvimento tecnológico, bem como da liberdade de pesquisa e da experimentação científica. Menos nova em via de princípio, porque projetada com a estipulação dos direitos sociais nas cartas constitucionais e internacionais do segundo pós-guerra, mas, no entanto, nova e não menos dramaticamente carente no plano da efetividade, é a dimensão internacional de um constitucionalismo e de um garantismo dos bens sociais, a qual implica os enormes problemas da redistribuição global da riqueza e de uma futura política econômica supranacional coerente com ela.

O que se requer para tal fim é a construção de uma esfera pública global. Contra os processos de integração econômica que caracterizam a globalização, o crescimento da interdependência planetária gerada pela ameaça aos bens ecológicos, a crise da soberania dos estados, os deslocamentos das grandes empresas fora das suas fronteiras e de seu controle e à exploração crescente do trabalho não se tem desenvolvido uma esfera pública à altura dos novos poderes privados transnacionais. Disso resulta um vácuo de direito público que não pode ser preenchido pelo direito privado de produção contratual, no qual vai-se modelando o direito da globalização ${ }^{57}$ e que, naturalmente, ignora os interesses públicos e reflete indelevelmente a lei do mais forte. Pois que o mercado, pela sua natureza, não pode produzir uma esfera pública, absolutamente essencial para a tutela dos interesses gerais. Podem-se criticar e talvez processar por danos ao ambiente ou por omissão de socorro as grandes empresas poluidoras ou as empresas alimentícias ou farmacêuticas que não fornecem aos países pobres os medicamentos essenciais. Podese afinal reconhecer que é no interesse conjunto do próprio mercado o desenvolvimento de uma esfera pública à altura de suas atuais dimensões

\footnotetext{
57 Veja-se, sobre o direito da globalização elaborado pelos escritórios de advocacia das grande empresas, nas formas privadas do contrato mais do que nas públicas, gerais e abstratas da lei, Ferrarese (2000). Veja-se, ainda, sobre as formas prevalentemente privatísticas do direito global hodierno, Galgano (2000); Irti (1998); Faria (1999), trad. esp., El derecho en la economía globalizada, Trotta, Madrid 2001; Portinaro (COSTA; ZOLO, 2002); Allegretti (2002); Ferrarese (2002).
} 
globais, assim como o foi, de resto, a formação de uma esfera pública estatal nas origens do capitalismo. Mas é absurdo esperar que as empresas isoladas - isto é, o mercado, além da política - façam-se espontaneamente portadores de interesses públicos, como a tutela do ambiente ou o socorro às populações indigentes. É impensável que os interesses gerais - como a paz, a segurança contra as causas sociais da criminalidade e do terrorismo, a conservação do planeta - sendo, a longo prazo, seguramente do interesse de todos e do próprio capitalismo, possam fazer parte do horizonte do capitalista individualizado; assim como seria impensável que o trânsito nas estradas ou a prevenção dos crimes, que claramente são do interesse de cada um, possam ser regulados e garantidos pela autonomia individual em vez de pela sinalização viária e normas penais, enquanto normas heterônomas de caráter geral e abstrato.

Não existem, portanto, alternativas racionais a um futuro de violências e catástrofes que não seja a construção de uma esfera pública planetária, absolutamente essencial à garantia dos bens fundamentais: precisamente, de uma esfera heterônoma em condições de assegurar, de um lado, a imunidade dos bens personalíssimos e comuns da sua apropriação e devastação, e, de outro, a distribuição e o acesso de todos aos bens sociais. Requerem-se para tal finalidade, duas condições: uma de caráter institucional, outra de caráter político e cultural.

A primeira condição, de caráter jurídico e institucional, é a definição normativa dos bens fundamentais em Cartas constitucionais e internacionais e, correlativamente, a produção de uma adequada legislação garantista de atuação: o reforço e a redefinição dos poderes e das competências das atuais instituições de garantia, como a FAO e a OMS; a criação de novas instituições internacionais de garantia primária sob a forma de Autoridades supranacionais independentes, para a tutela do ambiente e do acesso de todos à água potável; a criação de instituições jurisdicionais de garantia secundária em condições de sancionar o inadimplemento e as violações das garantias primárias. Mas, sobretudo, é necessária, no plano institucional, a introdução de um fisco mundial, isto é, de um poder supraestatal de taxação voltado a procurar - para além das atuais políticas de auxílio, as quais, diga-se, são vergonhosamente carentes com respeito até aos esforços despendidos - os recursos necessários 
para financiar as despesas sociais globais por obra das instituições supranacionais de garantia antigas e novas.

Move-se nesta direção a proposta da Tobin tax sobre as transações internacionais; ${ }^{58}$ mas há uma segunda via, bem mais fecunda, de exação fiscal global, que é indicada justamente na perspectiva da garantia dos bens comuns. Estes bens - a atmosfera, o equilíbrio ecológico, o espaço aéreo, as órbitas satelitais, as bandas do éter, os recursos minerais do solo marinho - são bens de todos ("patrimônio comum da humanidade", como dizem para cada um deles os Tratados internacionais), cujo uso, desfrute e dano têm acontecido até hoje a título gratuito, como se fossem res nullius, em vantagem dos países ricos que foram e ainda são seus principais usuários. Já recordei, no $\S 6$, que os principais responsáveis pelo aquecimento global e suas enormes consequências danosas que recaem sobre tudo nas populações pobres, são os países ricos, que com 15\% da população mundial, provocam hoje, acrescidos do desenvolvimento industrial da China e da Índia, a metade das emissões de gases estufa. ${ }^{59}$ Pois bem, por essas emissões e pelos danos gravíssimos que acarretam à saúde e à sobrevivência de todos os pobres do mundo, existe uma responsabilidade jurídica, civil e não somente política, imputável aos países ricos e a suas empresas. E existe, portanto, sobre a base de elementares princípios de direito privado, além da proibição, a obrigação de ressarcimento do dano atribuível a todos quantos hajam provocado tal dano. ${ }^{60}$

58 Sobre a proposta da Tobin tax, feita pelos movimentos "no global" cf. a obra de Bellofiore e Brancaccio (2002), que recolhe em apêndice uma série de textos, entre os quais o artigo de seu promotor James Tobin (p. 46-60): “A Proposal for International Monetary Reform” (1978), suas duas intervenções de 1997 no Washington Post e uma entrevista por ele concedida em 1999.

59 Rapporto 2007-2008 cit., p. 28. Em seu conjunto, os países ricos têm produzido, desde o início da era industrial, 70\% das emissões de gases estufa: 1.100 toneladas per capita no Reino Unido e nos Estados Unidos, sendo 66 toneladas per capita na China e 23 na Índia (id, p. 67). Sobre a maior “destruição ecológica” dos países ricos e as consequentes catástrofes nos países pobres, veja-se supra, as notas 32-35.

6058 Existem, outrossim, nesse sentido, importantes precedentes. O Rapporto 20072008 cit, p. 232, refere que, em 1998, os procuradores gerais de cinco estados americanos e de 18 cidades ajuizaram uma causa contra um grupo de fazendas produtoras de tabaco 
Não só isso. Também a simples utilização dos bens comuns, como o espaço aéreo e as órbitas satelitais, deveria comportar a obrigação para os usuários de pagar, pelo enriquecimento indébito, uma adequada retribuição aos coproprietários, isto é, à comunidade internacional. É claro que as somas devidas, seja a título de ressarcimento dos danos até hoje e ainda agora provocados, seja a título de indenização, ou melhor, de taxação pelo enriquecimento ilícito provenientes da utilização dos bens comuns não deterioráveis, ${ }^{61}$ seriam mais do que suficientes não somente para pagar as dívidas externas dos países pobres, mas também para financiar toda a despesa social requerida pela nova esfera pública global.

A segunda condição, prejudicial à primeira, da construção desta esfera pública global, é a superação, necessária para o desenvolvimento de um constitucionalismo a longo prazo e de grandes espaços, da aporia da democracia assinalada no $\S$ 6: a cessação da desinformação, do desinteresse e da ignorância em torno às atuais emergências globais e às novas tecnologias da informação, de uma opinião pública mundial que assuma os interesses planetários como novo parâmetro e medida do interesse público geral. Somente a maturação de uma conscientização geral sobre as interdependências do planeta e a gravidade do problema que afetam a totalidade do gênero humano pode de fato promover uma "política interna do mundo"62 em condições de afrontar as tantas

pelo dano à saúde provocado por ele, obtendo a condenação ao pagamento, a título de ressarcimento, de 206 bilhões de dólares; e que em 1989, pelo dano ambiental provocado por 42 milhões de litros de óleo cru jogados no mar do Alaska após um incidente, a Exxon Valdez foi processada por danos, em 2 bilhões de dólares.

61 Sob bases análogas, o internacionalista David Everett Marko propôs uma taxação internacional sobre a exploração dos recursos minerais dos solos oceânicos em 3,57\% (idêntica àquela prevista nos Estados Unidos para a extração dos minerais do subsolo) do valor do material extraído para destiná-la a um "Fundo em favor do desenvolvimento" (D. E. Marko, “A Kinder, Gentler Moon Treaty: a Critical Rewiew of the Treaty and proposed Alternative”, in: Journal of Natural Resources and Environmental Law, 1992). De forma análoga, Giovanni Franzoni propôs uma taxação sobre o uso das órbitas satelitais em torno da Terra e das bandas do éter em benefício de um "Fundo para o abatimento da dívida e pelo desenvolvimento” (FRANZONI, 2000, p. 91-113).

62 A expressão “política interna do mundo” foi adotada por J. Habermas: “Con la fine dell'equilibrio del terrore, sembra che sul piano della politica internazionale della sicurezza e 
emergências planetárias e de transformar tais emergências numa ocasião histórica, sem precedentes e irrepetível, de integração política e jurídica planetária. Este novo sentimento cívico deveria fundar-se sobre um novo sentido de pertencimento comunitário, alargado ao gênero humano inteiro, e sobre a percepção como problemas políticos primários e como interesses públicos vitais dos problemas e dos interesses globais, ligados todos, de variadas formas, à garantia dos bens fundamentais. Uma vez que são interesses comuns, que atravessam as fronteiras e as gerações, não apenas a garantia dos bens comuns, mas também dos bens sociais, das quais dependem, além do crescimento econômico dos países pobres, a convivência pacífica, a segurança, a redução dos fluxos migratórios e o desenvolvimento, sob o signo da igualdade em direitos, dos processos de emancipação social, de integração global e democratização política.

Sob esse aspecto, pode-se bem dizer que um primeiro embrião de opinião pública global em condições de pedir a promoção de políticas e instituições de garantia supraestatais expressou-se nestes últimos anos, paradoxalmente, pelos movimentos chamados “no global”. Não é de fato ousado afirmar que, para além dos rótulos, os verdadeiros adversários de um mundo globalizado têm sido, até hoje, sobretudo os governos dos países mais ricos, que têm defendido um arranjo capitalista mundial fundado sobre a desigualdade, sobre as soberanias nacionais, sobre o fechamento das fronteiras aos fluxos migratórios, sobre a ausência de limites ao mercado e ao desenvolvimento industrial e sobre um substancial isolacionismo do Ocidente; enquanto os mais ferrenhos defensores do globalismo jurídico têm sido os jovens que no mundo todo têm-se mobilizado, por ocasião das cúpulas do G8, na reivindicação da paz, na defesa do meio ambiente, na rejeição do atual modelo de

dei diritti umani si sia dischiusa - nonostante tutti i contraccolpi - una prospettiva per ciò che C.F. von Weizsäcker ha definito 'politica interna del mondo' [Weltinnenpolitik]' (Die Einbeziehung des Anderen [1996], tr.it. de L. Ceppa, L'inclusione dell'altro. Studi di teoria politica, Feltrinelli, Milano 1998, p.139). A expressão foi retomada por J. Habermas, Die postnationale Konstellation (1998), tr. it. de L. Ceppa, La costellazione post-nazionale. Mercato globale, nazioni e democrazia, Feltrinelli, Milano 1999, p. 26 e 90-101, e depois por Bonanate, (2001): La politica interna del mondo, in “Teoria politica”, XVII, 2001, n.1, p. 20. 
desenvolvimento insustentável e na exigência de uma regulação dos mercados, de uma maior justiça distributiva e da igualdade nos direitos fundamentais de todos os seres humanos prometida por tantas cartas constitucionais e internacionais. É pela expansão destes movimentos de contestação das formas atuais da globalização sob o signo do slogan “um outro mundo é possível”, que pode nascer, se prevalecer a razão, uma sociedade civil mundial unida na construção duma nova ordem constitucional global, guiada pelo ideal de um único destino de todos os seres humanos e pela luta transnacional pelo direito, pelos direitos e pelos bens fundamentais.

\section{Referências}

AA.VV. L'eau, patrimoine commun de l'humanité. Paris: Centre Tricontinental, L'Harmattan 2002.

AA.VV. Human Development. Report 2007/2008. Fighting climate change. Human solidarity in a divided world, tr.it. Lo sviluppo umano. Rapporto 2007-2008. Resistere al cambiamento climatico, Turim: Rosenberg e Sellier, 2007.

AA.VV. Human Development Report 1999, trad. it., Rapporto 1999 sullo sviluppo umano. 10. La globalizzazione. Turim: Rosenberg e Sellier, 1999

ALLEGRETTI, U. Diritti e Stato nella mondializzazione, Città Aperta: Troina, 2002;

ARE, M. Benne immateriali. Enciclopédia del diritto, v. V, 1959.

BARBERO, D. Sistema del diritto privato italiano, IV. Turim: ed. Utet, 1965.

BARBINA, G. Il piatto vuoto: geografia del sottosviluppo. Roma: Carocci, 2001;

BECCARIA, C. Dei delitti e delle pene, Torino: Einaudi, 1981. (Ed. di Livorno del 1766, aos cuidados de F.Venturi). 
BELLOFIORE R.; BRANCACCIO, E. (Org.), Il granello di sabbia: i pro e i contro della Tobin Tax. Milão: Feltrinelli, 2002.

BONANATE, L. 2001: La politica interna del mondo. In: Teoria politica, XVII, 2001, n. 1, p. 20.

COMPORTI, M. Le cose, i beni ed i diritti reali, In: BESSONE, M.

(Org.) Instituzioni di diritto privato, Turim: Giappichelli, 2003.

CORREGGIA, M. (Org.) Accesso ai farmaci: la malattia del profitto, dossiê de "Médicos sem fronteiras”, Roma: Abilgraf, 2002.

DE VILLIERS, M. Water: the fate of our precious resource, New York/ Houghton: Mifflin, 2000.

FARIA, J. E. O direito na economia globalizada. Trad. esp. El derecho en la economía globalizada, Madrid: Trotta, 2001.

FERRAJOLI, L. Principia iuris: teoria del diritto e della democrazia. Roma/Bari: Laterza, 2007.

FERRAJOLI, L. Diritto civile e principio di legalità. In: Il diritto civile oggi: compiti scientifici e didattici del civilista. Napoli: Edizioni Scientifiche Italiane, 2006.

FERRAJOLI, L. La crisis de la democracia en la era de la globalización. In: ESCAMILLA; SAAVEDRA (Ed.): Derecho y justicia en una sociedad global: law and justice in a global society. Anales de la Cátedra Francisco Suárez, n. 39, 2005.

FERRAJOLI, L. Diritti fondamentali: un dibattito teórico [2001], III ed., Roma/Bari: Laterza, 2008.

FERRAJOLI, L. Tre concetti di liberta. In: Democrazia e dirito, 2001.

FERRAJOLI, L. Proprietà e liberta. In: Parolecchiave, n. 30, 2003.

FERRAJOLI, L. Per um costituzionalismo di diritto privato. In: Rivista critica del diritto privato, ano XXII, n. 1, mar. 2004.

FERRAJOLI, L. Diritto civile e principio di legalità. In: Il diritto civile oggi: compiti scientifici e didattici del civilista, Napoli: Edizioni Scientifiche Italiane, 2006. 
FERRAJOLI, L. Contra los poderes salvajes del mercado: para un constitucionalismo de derecho privado. In: CARBONELL, M. Democracia y garantismo. Madrid: Editorial Trotta, 2008.

FERRARESE, M. R. Le istituzioni della globalizzazione: Diritto e diritti nella società transnazionale. Bolonha: Il Mulino, 2000.

FERRARESE, M. R. Il diritto al presente: globalizzazione e tempo delle istituzioni. Bolonha: Il Mulino, 2002.

FRANZONI, G., Anche il cielo è di Dio. Il credito dei poveri. Roma: Edup, 2000.

GALGANO, A. Lex mercatoria. Bolonha: Il Mulino, 2000.

HABERMAS, J. Die Einbeziehung des Anderen [1996], tr.it. de L.Ceppa, L'inclusione dell'altro. Studi di teoria politica, Milão: Feltrinelli, 1998.

HABERMAS, J. Die postnationale Konstellation (1998), tr.it. de L.Ceppa, La costellazione post-nazionale. Mercato globale, nazioni e democrazia. Milão: Feltrinelli, 1999.

HOLMES S.; SUNSTEIN, C.R. The Costs of Rights: why Liberty depends on Taxes, (1999), trad.it.: Il costo dei diritt: perché la libertà dipende dalle tasse, Bolonha: Il Mulino, 2000.

IRTI, N. L'ordine giuridico del mercato. Roma/Bari: Laterza, 1998.

KANT, I. Principi metafisici della dottrina del diritto (1797). In: BOBBIO, N;. FIRPO, L; MATHIEU, V. (Org.) Scritti politici e di filosofia della storia e del diritto. Turim: Vidari/Utet, 1965.

KANT, I. Die Metaphysik der Sitten, (1797), trad. it. di G. Vidari: La metafisica dei costumi, Bari: Laterza, 1970.

LOCKE, J. Second Treatise of Government, (1690), trad.it. di L.

Pareyson: Due trattati sul governo: secondo trattato. Turim: Utet, 1968.

LUCARELLI, A; MAROTTA, S. Governo dell'acqua e diritti fondamentali: una battaglia contro la privatizzazione, Napoli: Palazzo Margliano, 2006. 
MARKO, D. E. A Kinder, Gentler Moon Treaty: a Critical Rewiew of the Treaty and proposed Alternative. In: Journal of Natural Resources and Environmental Law, 1992.

MESSINEO, G. Manuale di diritto civile e commerciale, IX ed., Milão: Giuffrè, 1957.

MESSINETTI, D. Oggetto dei diritti. In: Enciclopedia del diritto. Milão: Giuffrè, 1979, vol. XXIX.

MOLINARI, E. L'acqua, bene comune dell'umanità. Il movimento mondiale: successi e problem. In: Quale Stato, 2006, n.2/3, p. 197-210. NASH, R. F. The Rights of Nature, Madison: The University of Wisconsin Press, 1989.

NEBBIA, G. Il problema dell'acqua, Cacucci, Bari: Cacucci, 1999. ORGANIZAÇÃO DAS NAÇÕES UNIDAS. Tratado sobre o espaço estratosférico, 1967.

ORGANIZAÇÃO DAS NAÇÕES UNIDAS. Convenção sobre o direito do mar, 1982.

ORGANIZAÇÃO DAS NAÇÕES UNIDAS. World Charter for Nature, 1982.

ORGANIZAÇÃO DAS NAÇÕES UNIDAS. Earth Charter, 1992.

ORGANIZAÇÃO DAS NAÇÕES UNIDAS. Framework Convention on Climate Change, 1992.

ORGANIZAÇÃO DAS NAÇÕES UNIDAS. Convention on Biological Diversity, 1992.

ORGANIZAÇÃO DAS NAÇÕES UNIDAS. Protocolo de Kyoto, 1997. ORGANIZAÇÃO MUNDIAL DA SAÚDE. Relatório, 2000.

ORGANIZAÇÃO MUNDIAL DO COMÉRCIO, Trade-Related Aspects of Intellectual Property Rights, 1996.

“PAROLECHIAVE”, 27, 2002; (fascículo Acqua). 
PETRELLA, R. Il Manifesto dell'acqua: Il diritto alla vita per tutti. Turim: Gruppo Abele, 2001.

PETRELLA, R. Il bene comune. Elogio della solidarietà. Reggio Emilia: Diabasis, 2003. (Prefácio de Luciano Gallino).

PISARELLO, G. Vivienda para todos: un derecho en (de)costrucción. El derecho a una vivienda digna y adecuada como derecho exigible. Barcelona: Icaria, 2003.

PORTINARO, P. P. Oltre lo Stato di diritto. Tirannia dei giudici o anarchia degli avvocati? In: COSTA, P.; ZOLO, D. (Org.), Lo Stato di diritto: storia, teoria, critica. Milão: Feltrinelli, 2002.

PUREZA, J. M. El patrimonio común de la humanidad. ¿Hacia un Derecho internacional de la solidariedad? Madrid: Trotta, 2002.

REPÚBLICA DA BOLÍVIA. Constituição de 2008.

REPÚBLICA DO EQUADOR. Constituição de 2008.

SENESE, S. Un nuovo soggetto di diritti: l'umanità. In: BALDUCCI, E. Le tribù della terra: orizzonte 2000. San Domenico di Fiesole: Edizioni Cultura della Pace, 1991.

SERRES, M. Le contrat naturel, (1990), trad. it.: Il contratto naturale, Milão: Feltrinelli, 1991.

SHIVA, V. Water Wars (2002), trad. it., Le guerre dell'acqua, Milão: Feltrinelli, 2003.

STONE, T. C. Should Trees Have Standing? Toward Legal Rights for Natural Objects. Palo Alto: Tioga Publishing Co., 1988.

TALLACCHINI, M. Diritto per la natura: Ecologia e filosofia del diritto. Turim: Giappichelli, 1996.

TOGNONI, G. I farmaci essenziali come indicatori di diritto. In:

Giornale italiano di farmacia clinica, 12, 2, abr./jun. 1998, p. 116-122.

TORRENTE, A; SCHLESINGER, P. Manuale di diritto privato, XIV ed. Milão: Giuffrè, 1994. 
VIOLA, F. Dalla natura ai diritti: i luoghi dell'etica contemporânea. Roma/Bari: Laterza, 1997.

VIOLA, F. Etica e metaetica dei diritti umani, Turim: Giappichelli, 2000. WINDSCHEID, B. Lehrbuch des Pandektenrechts, [1862-1870], trad. it. de FADDA, C.; BENSA, P. E. Diritto delle Pandette. Turim: Utet, 1902. www. Carbon Dioxide Information Analysis Center. Acesso em: 05 jun. 2009.

ZIEGLER, J. Le droit à l'alimentation. Paris: Mille et une Nuits/Fayard, 2002.

ZOLO, D. Il diritto all'acqua come diritto sociale e come diritto collettivo. Il caso palestinesse. In: Diritto pubblico 1, 2005, p. 125-142. 